\title{
Medialność Jezusa Chrystusa
}

\author{
Daria Kania \\ Chrześcijańska Akademia Teologiczna, Wydział Teologiczny, Polska \\ ORCID: 0000-0002-3739-6286 \\ dariakania@op.pl
}

D. Kania, Mediality of Jesus Christ, Elpis, 22 2020: 17-31.

\begin{abstract}
Media create the worldview, mentality and ethical attitudes. In the cultural perspectives it often intensifies as one of the many oppressive attitudes that culture applies to people. However, the theological perspective has a different approach. In the Holy Bible, we already find forms of broadly understood mediality, which - in the article - is understood not only as influences on people, but also as a form of communication, especially in the light of the relation Creator-Creation. At the same time, the concept of anthropology of the Eastern Church adopted in the thesis aims at the subject of reflection on anthropology and mysticism, leading man to the path of knowing God. This knowledge becomes possible only within the Church: a living organism with the head of the Savior, Jesus Christ. In an attempt to analyze mediality of the Second Person of the Holy Trinity, the article does not ignore any of the hypostases of the indissoluble Holy Trinity. The Old Testament God appears here from the beginning as a media. The New Testament Son of God, the Savior Jesus Christ, becomes a man, to give a man the opportunity to reunite with God, after centuries of lost communication, which is a consequence of the sin of the forefathers Adam and Eve. And the Comforter, the Holy Spirit, both in ecclesiological and individual dimensions, enables this unity. In the light of the issues addressed in the article, the mediality of Jesus Christ has been treated in many aspects.
\end{abstract}

\begin{abstract}
Streszczenie: Media zarówno tradycyjne, jak i tzw. nowe media, kształtują światopogląd, mentalność, postawy moralne i etyczne. W perspektywie kulturoznawczej mechanizmy medialne analizowane są często jako jedna z licznych postaw opresyjnych. Perspektywa teologiczna nakreśla zgoła odmienne podejście. W Piśmie Świętym odnajdujemy już formy szeroko pojętej medialności, którą - w artykule - rozumie się nie tylko jako czynniki oddziaływania i wywierania wpływu na ludzi, ale również jako formę komunikacji, szczególnie w świetle relacji Stwórca-Stworzenie. Jednocześnie przyjęta w pracy koncepcja antropologii Kościoła Wschodniego kieruje temat rozważań w kierunku antropologii i mistycyzmu, prowadzącego człowieka na drogę poznania Boga. Poznanie to staje się możliwe wyłącznie wewnątrz Kościoła: żywego organizmu, którego głową jest Zbawiciel, Jezus Chrystus. Artykuł podejmując próbę analizy medialności Drugiej Osoby Trójcy Świętej, nie pomija jednocześnie żadnej z hipostaz nierozerwalnej Trójcy Świętej. Starotestamentowy Bóg jawi się tu od początku jako medialny. Nowotestamentowy Syn Boży, Zbawiciel Jezus Chrystus, staje się człowiekiem, by dać człowiekowi możliwość ponownego zjednoczenia się z Bogiem, po wiekach utraconej łączności, będącej konsekwencją grzechu praojców Adama i Ewy. A Pocieszyciel, Duch Święty, zarówno w wymiarze eklezjologicznym, jak i indywidualnym, umożliwia tę jedność. W świetle podejmowanych w artykule zagadnień, medialność Jezusa Chrystusa została potraktowana wieloaspektowo.
\end{abstract}

Keywords: media, culture, anthropology, Bible, Christology

Slowa kluczowe: media, kultura, antropologia, Biblia, Chrystologia

\section{Wprowadzenie}

Wiek XXI to czas dominacji mediów. Niezależnie od form jakie przybierają, media w sposób świadomy i realny kształtują dziś postawy i system wartości społeczeństw. Skuteczność ich działań decyduje o postawach politycznych, konsumenckich, czy światopoglądowych, a co za tym idzie, także i moralnych. Czas wielkich narracji historycznych (Lyotard, 1997, s. 25-35) zastąpił dziś marketing narracyjny (Lewek, W: Studia Theologica Varsa, 1998, s. 90-98). Niestety, odnosi się to również do kwestii dotyczących wiary, etyki czy moralności, gdzie - na wzór marketingowy - zapanowała zasada rynkowa. Ciągle więc aktualna zdaje się być XX-wieczna koncepcja antropologiczna, wedle której człowiek, jako jednostka będąca częścią przyrody świata stworzonego, zmaga się z nieustannym uciskiem zewnętrznej kultury i historii będącej dla niego źródłem cierpień (Orłowski, 1994, s. 203-208). Zmienił się wszakże punkt odniesienia. Świat wartości i poszukiwania sensu życia w kontemplacji mi- stycznego doświadczenia (Evdokimov, 1986, s. 139-153) transcendentalnego Boga został sprowadzony do pościgu ku realizacji własnych indywidualnych potrzeb, mających stać się ukojeniem. Następuje więc odwrócenie całego aparatu aksjologicznego, który teraz nie zostaje poszukiwany wśród pozaludzkich transcendentalnych czynników, a w świecie, gdzie brak takich odniesień. Tymczasem, historycznie rzecz ujmując, jednostki zawsze poszukiwały sensu i znaczenia (Wils, 2014, s. 11-30) swej egzystencji właśnie w religii; ta funkcja - niezależnie od definicji religii - do dziś pozostaje nienaruszona. Zmienił się natomiast stosunek ludzi do religii.

W tym kontekście nie można pominąć odniesienia do problemu masowości, o którym zaczęto toczyć dyskusję już w XX wieku (Gasset, 2002, s. 31-33). Mając na względzie towarzyszące umasowieniu: m.in. degradację jakości oraz unifikację przeciętności, można natrafić na kolejny aspekt zagadnienia związanego z medialnością, mianowicie staje się ona narzędziem umożliwiającym zaistnienia w powszechnym dyskursie postaw jednostkowych, które 
roszczą sobie pretensję do powszechności. Jako aktywni uczestnicy kultury obserwujemy dziś wszelkiego rodzaju próby wybicia $\mathrm{z}$ tłumu wszechogarniającej tuzinkowości. Kultura zmusza nas do tego, aby z anonimowego uczestnika kultury przeobrazić się $\mathrm{w}$ indywidualną jednostkę, a w tym procesie obowiązuje naczelna zasada: jeśli nie funkcjonujesz w mediach - nie istniejesz. Chcesz zaistnieć musisz umiejętnie się sprzedać. Maksyma ta obowiązuje zarówno w polityce, sztuce, jak i w nauce.

Humanistyka schyłku XX, dokonując analizy nowego modelu kultury, dostrzegła już, że postępująca szybkość życia wraz z daleko posuniętym rozwojem cywilizacyjnym i postępem technicznym, prowadzi jednostkę do degradacji. Ponad masową przeciętność przebijają się nowe postawy i idee, a co za tym idzie, wraz z nimi pojawia niebezpieczeństwo bluźnierstwa (Wils, 2014, s. 23) czynionego wobec wszelkich dotychczasowych świętości. To, co transcendentalne, święte, zostaje zastąpione przez to, co świeckie, nadając temu jedocześnie taką samą wartość, jak dotychczasowym świętościom (Durkheim, 2010, s. 56)1. Nie chodzi tutaj wyłącznie o boski wymiar świętości, a więc o poznanie immanentnych cech Boga oraz Świętych, doświadczanych w indywidualnym przeżyciu religijnym, ale również o świecki, wspólnotowy i społeczny wymiar świętości. Protestancki teolog i fenomenolog Rudolf Otto pisząc o świętości podkreślał istotę indywidualnego doświadczenia religijnego, wewnętrznego psychicznego przeżywania sfery sacrum (Otto, 1999, s. 9-10, 133, rozdz. 16 i 19$)^{2}$. Z kolei Mircea Eliade wskazywał na zewnętrzne i także społeczne przejawy świętości w rzeczywistości świeckiej, tj. w hierofaniach (Eliade, 1999, s. 7; Eliade, 2009, s. 11-14). Nie chcąc wdawać się w kwestie dogmatyczne, konfesyjne i filozoficzne, trzeba wskazać, iż "świętość” zawsze była integralną częścią życia człowieka, artykułowaną nie tylko w koncepcjach światopoglądowych, ale - przede wszystkim - stale obecną w Starym i Nowym Testamencie. Przyjmując na potrzeby tej pracy postawy starosłowiańskiej tradycji Kościoła Wschodniego, które naucza, iż „Świętość jest mocą, która przemienia człowieka tak, że staje się inny" (Charkiewicz, 2013, s. 102) , war-

\footnotetext{
Emile Durkheim, oddzielając sacrum od profanum i wskazując jednocześnie na socjologiczne aspekty świętości, podkreślił, że twórcą rzeczy świętych jest społeczeństwo i wskazywał na czynniki sacrum jako na elementy służące integracji społecznej, podkreślając przy tym siłę reprezentujących te świętości społeczeństw. Autorytet przynależny rzeczom świętym, jest autorytetem społeczeństwa - uważał.

Protestancki teolog Rudolf Otto rozwiną termin „świętość” wprowadzając go do kategorii ludzkiego doświadczenia religijnego i rozróżniając na elementy irracjonalne i racjonalne. Aprioryczne, transcendentalne formy przeżywania sacrum, które - jak zaznacza - mają charakter pozaracjonalny, ponadrozumowy i irracjonalny, oddziałują na wewnętrzny stan przeżycia ludzkiego. To fenomenologiczne podejście Otto można zestawić z innymi koncepcjami względem świętości. Jak pisał: „Świętość w pehnym znaczeniu tego stowa jest więc dla nas kategoria złożona. Sktadajace się na niq elementy stanowia jej racjonalne i irracjonalne części składowe. Co do obydwu elementów jest ona jednak - co należy podkreślić z cała moca wbrew wszelkiemu sensualizmowi i wszelkiemu ewolucjonizmowi - czysta kategoria a priori"

3 Autor rozpatrując etymologicznie termin „świętość” wskazuje, że pochodzi on od hebrajskiego słowa „qodeš” i - biorąc pod uwagę pojemność semantyczną - uznaje, że należy rozpatrywać go w dwóch aspek-
}

to wskazać w tym miejscu, że według nauki patrystycznej świętych Ojców i tradycji Kościoła prawosławnego, każdy człowiek - dzięki kenozie Drugiej Osoby Trójcy Świętej jest powołany przez swego Stwórcę do stania się świętym. Tak jak Bóg stał się człowiekiem, tak człowiek może stać

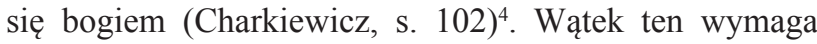
szerszego omówienia i zostanie przedstawiony poniżej, został jedynie przywołany w tym miejscu w celu wskazania niebezpieczeństwa, jakie może nastręczyć siła medialnych komunikatów przebijających się do społecznego dyskursu ze strony przedstawicieli różnych perspektyw, z uwagi na fakt, iż mówimy o debacie dotyczącej kwestii etyki, moralności i „świętości”. Pojawiający się często argument, obarczający sam nośnik medialny za owo niebezpieczeństwo, jest nie tyle niefortunny, co wręcz naiwny.

Mimo iż medialność współczesnego świata zmierza ku absurdom, nie oznacza to jednak, że - jako narzędzie służące komunikacji i docieraniu do szerokiej rzeszy odbiorców - ma tylko złe oblicze. Co więcej, w swoim założeniu, nie jest niczym nowym. Media nie są wynalazkiem ani naszych czasów ani innych epok. Zawsze były, są i będą, choć - patrząc z perspektywy czasu - ulegają także stałym przeobrażeniom. Jak wykazały badania (McLuhan, 2004) wynalezienie druku, rozwój kultury telewizyjnej, a także rewolucja internetowa - zdjęly z przekazu aurę elitarności i ukazały nowy walor komunikacji. Nie jest jednak ważne, czy mówimy o Internecie, kazalnicy, gazecie, papieskiej bulli, czy podeście na targu - mechanizm docierania do ludzi i do tłumów zawsze jest ten sam: ułatwia głoszenie tez i rozpowszechnianie wyznawanych wartości. W każdym okresie historycznym i epoce wiedziano, że jeśli chce się zostać usłyszanym, należy czynić to w taki sposób i w takich miejscach, by jak największe grono odbiorców miało sposobność cię usłyszeć. Medialność znana jest od niepamiętnych czasów. Czyż Bóg przemawiający z gorejącego krzewu do Mojżesza na Synaju nie jest medialny (Wj 3,1-7). Zadziwia, porusza, skłania do refleksji, analizy - brakuje jedynie licznej grupy odbiorców. Adresatem jest jedynie Mojżesz. Podobnie w czasie ofiarowania dziesięciu przykazań. Brakuje jedynie słuchaczy. Ale i to się z czasem zmienia (Wj 19,10-20) - Mojżesz przemawia w pałacu faraona $(\mathrm{Wj} 7$; $\mathrm{Wj} 12)$. Czyż za jednym nie podążyły na pustynię tłumy? I czy Ten, który chciał być usłyszany, istotnie nie został usłyszany?

Spójrzmy teraz na Nowy Testament. Syn Boży, Jezus Chrystus, wciela się w człowieka, aby zmienić oblicze ca-

tach, które wskazują na ukierunkowanie ku człowiekowi. Pierwszy oznacza „oddzielenie” (od grzechu), „oczyszczenie”, drugi - „wydzielenie” i „poświęcenia dla Boga”. Jak wskazuje, w Starym Testamencie „Bóg objawit siebie Ś więtym po to, aby człowiek mógł tę świętość poznać (por. Wj 29,43-45; Lb 20,6.13"). W Nowym Testamencie następuje zmiana. $\mathrm{Ci}$, którzy uwierzyli we wcielenie się Logosu i przyjście na świat Jezusa Chrystusa, zostają wezwani do „nowego życia” wiodącego tylko przez Drugą Osobę Trójcy Świętej.

4 Autor zaznacza, że „,podczas gdy 'stara' (Ef 4,22) natura czlowieka jest dziedziczona przez potomków Adama w porzadku naturalnym, to zrodzenie z 'Nowego Adama'(1 Kor 15,45.47; por. Ef 4,24) oraz wspólnota $z$ Duchem Świętym dokonuje się w procesie osobistej aktywności człowieka". 
łej ludzkości. Wpływa, oddziaływuje, naucza jak największą rzeszę mas społecznych. Pragnie ukazać im prawdziwy sens Starego Testamentu, ofiarować Nowy, by doprowadzić do aktywnego wysiłku, ku zbawieniu ich dusz. By to osiągnąc, sięga do niespotykanych wcześniej metod, a może właściwszym będzie stwierdzenie, że stare metody wynosi na niespotykany dotychczas stopień medialnej doskonałości.

Warto więc postawić tu pytanie, czy zatem Jezus Chrystus był osobą medialną?

\section{Medialność. Jestem tym, o którym głosi Pismo}

Przyjęło się powszechnie uznawać, iż w trakcie ziemskiej wędrówki Jezusa, Jego, publiczna działalność rozpoczyna się od chrztu w Jordanie. Jednak, jeśli przyjrzymy się wnikliwie wszystkim czterem ewangeliom, zauważymy, że rozpoczyna się już od Jego narodzenia w betlejemskiej grocie. Pozornie jednak wydaje się, że wydarzenie to było skryte przed oczami mas. Faktycznie było wręcz odwrotnie. Narodziny Jezusa Chrystusa są jednym z najbardziej medialnych dzieł Zbawiciela. Przyjrzyjmy się temu bliżej.

Analizując to wydarzenie w kontekście medialności, już na wstępie trzeba zaznaczyć, iż było ono zwiastowane poprzez proroków jeszcze w Starym Testamencie. Jedną z najstarszych zapowiedzi o przyjściu Zbawiciela znajdujemy w drugiej księdze Samuela, w której król Dawid opowiadając o planach budowy świątyni dla Jahwe - słyszy od Boga, przemawiającego do Niego ustami Natana: „,To nie ty Mi zbudujesz dom (hebrajski rzeczownika bajit, tj. dom - uzyte $w$ dwojakim znaczeniu, tu jako - światynia), ale ,Ja tobie zbuduje dom (ten sam rzeczownik użyty w znaczeniu- dynastia) (Jaworski, 2015, s. 1-6; Brzegowy, 2008, s. 5-27). Choć oczywiście celem tego artykułu nie jest przytaczanie wszystkich przykładów ze Starego Testamentu zapowiadających narodziny Zbawiciela, a powyższe nawiązanie do przyjścia mesjasza z rodu dawidowego nie jest jedynym, warto podkreślić interesujący wątek dotyczący tego wydarzenia, znajdujący się w Księdze Izajasza (Lemański, 2002, s. 49-64). „Dlatego Pan sam da wam znak: Oto Panna pocznie i porodzi Syna, i nazwie go imieniem Emmanuel" (Iz 7,14). Wśród biblistów i egzegetów do dziś toczy się dyskusja na temat znaczenia i interpretacji (zarówno tej historycznej, jak i mesjanistycznej) proroctwa zawartego w słowach Izajasza dotyczących narodzin Zbawiciela (Lemański, 2002, s. 5-7), o którym zwiastuje - iż, będzie to Emmanuel - co oznacza „Bóg z nami”, a więc Bóg Jahwe zamieszka z nami (Brzegowy, 1994, s. 94-96; Synowiec, 1992, 73-77). Niezależnie jednak od perspektywy jaką przyjmiemy przy analizie tego fragmentu Pisma, zawsze odczytamy ją w kategoriach „znaku” (Evdokimov, s. 286-287)5. W tym przypadku - znaku czynionego przez

\footnotetext{
5 Semiotyka, nauka o znakach, zakłada - za Ferdinandem de Saussure'm - że znak składa się z elementu znaczącego (będącego jego zewnętrznym materialnym, akustycznym czy graficznym reprezentantem) oraz znaczonego (będącego odniesieniem tego pierwszego do świata, myśli,
}

Boga i zwiastującego obietnicę zbawienia (Jaworski, 2015, s. 6) - o takim odczytaniu świadczą późniejsze nawiązania znajdujące się w Nowym Testamencie (Brzegowy, 2008, s. 25), gdzie apostoł Mateusz zaświadcza, że faktycznie wypełniło się Słowo. „A stało się to wszystko, aby się wypełniło słowo Pańskie wypowiedziane przez proroka: Oto Dziewica pocznie i porodzi syna, któremu nadadzą imię Emmanuel, to znaczy Bóg z nami” (Mt 1, 22-23).

Zostańmy jeszcze na chwilę przy samym akcie narodzin, by zwrócić uwagę na inną, choć równie istotną kwestię. Mianowicie: należy zauważyć, że samo zwiastowanie jest aktem medialnym Boga, w którym biorą udział nie tylko ludzie, ale także czynniki Boskie, tj. transcendentne. Wieści o narodzinach Jezusa obwieścili pasterzom aniołowie, a ich głoszenie było tak skuteczne, że ci prości ludzie porzucili swe stada, by nocą podążyć do Betlejem, a wracając do swych domów, ogłaszać innym, jakie dziwy ukazały im niebiosa. $\mathrm{W}$ odniesieniu do naszych dalszych rozważań niemal kluczowa staje się być jedna z najistotniejszych funkcji, jaką pełnią aniołowie, na którą wskazuje za św. Grzegorzem Wielkim autor „Angelologii św. Grzegorza Wielkiego". Pisze on, iż istoty duchowe, bezcielesne tylko wtedy są aniołami, kiedy coś zwiastują (Lachowicz, 1994, s. 165). Sięgając do Pisma, możemy zauważyć, że niewiasty idące do grobu Pańskiego z wonnościami (Mt 28, 1-8; Łk 24, 1-11) informuje o Zmartwychwstaniu Jezusa anioł, a św. Marię Magdalenę - dwaj aniołowie (J 20, 1-8, 11-15). O pośrednictwie aniołów w głoszeniu woli Bożej dotyczącej wcielenia - i co za tym idzie - całej ekonomii zbawienia rodu ludzkiego, mowa oczywiście także o chwili zwiastowania Maryi, kiedy archanioł Gabriel informuje młodą kobietą, kogo w istocie wyda na świat (Łk 1,31). Podobnie dzieje się w przypadku snów św. Józefa. To anioł uspokaja go we śnie, by nie lękał się poślubić brzemienną pannę, a także przekazuje mu, jakie imię otrzyma i zarazem jaką rolę odegra dziecko, które obawia się przyjąć pod swą opiekę (Mt 1,20-21). Anioł objawia się również w momencie niebezpieczeństwa, jakie czyha na Świętą Rodzinę ze strony prześladowców, i to on przekazuje Józefowi, kiedy ma zabrać Maryję z dzieckiem i opuścić niebezpieczne dla nich miasto. Analogiczna sytuacja powtarza się także później. Józef poprzez anioła dowiaduje się, kiedy ma powrócić do miasta (Mt 2,15). Nie ma wątpliwości, że aniołowie pełnią funkcję posłanników boskich, a poprzez ich posługę działa w świecie sam Bóg, Który za ich pośrednictwem przywołuje ludzi do wieczerzy w swoim królestwie (Psatterz złożony, tł. ks. Paprocki, str. 166).

Zatrzymajmy się na chwilę w tym miejscu, by uporządkować to, co wiemy na temat aniołów. Nie ma wątpliwości, iż angelologia zajmuje stałe miejsce $\mathrm{w}$ objawieniach staro i nowotestamentowych (Lachowicz, 1994, s. 153), a co za tym idzie i w teologii chrześcijańskiej. I choć stworzenie

pojęć). Znaczący element znaku jest w tym wypadu mesjanistyczny. Paul Evdokimov podobnie wskazuje, iż znak pośredniczy w przekazywaniu. W przeciwieństwie do symbolu, który uczestniczy w tym, co symbolizuje, „rzecz symbolizowana jest obecna w swoim symbolu”, jak w przypadku ikony. 
świata niewidzialnego potwierdza Wyznanie Wiary ${ }^{6}$, które naucza, że Bóg jest Stworzycielem świata widzialnego i niewidzialnego, to jednak przy opisie stworzenia świata, jak czytamy we fragmencie Księgi Rodzaju opisującym stworzenie przez Boga nieba i ziemi (Rdz 2, 1), nigdzie nie ma mowy o stworzeniu aniołów. W innym fragmencie Pisma odnajdujemy fragment, w którym sam Bóg poucza nas, że: „Gdy stworzone zostały gwiazdy, głosem wielkim chwalili mnie wszyscy aniołowie moi”. Analizując ten fragment Pisma, autor „Angelologii św. Grzegorza Wielkiego" przedstawia za św. Augustynem wniosek, iż aniołowie musieli istnieć już w momencie, gdy zostały stworzone gwiazdy, które - jak wskazuje Pismo - Bóg stworzył dnia czwartego (Św. Augustyn, 1977, s. 16, W: Lachowicz, 1994 s. 161) ${ }^{7}$. Św. Bazylii Wielki, jeden z największych Ojców Kościoła, wskazywał, iż Bóg stworzył świat duchowy „do momentu” stworzenia świata materialnego, a więc przed czasem i poza czasem (Fłorowskij, 1992, s. 65), jeszcze przed stworzeniem nieba i ziemi ( $\operatorname{Rdz} 1,1)$.

Nauka św. Bazylego jest zgodna z prawosławną teologię dogmatyczną, a także tym, co na temat aniołów czytamy Biblii, szczególnie w Psałterzu Dawidowym. Odnajdujemy tu wiele cennych informacji na temat aniołów. Podkreślona zostaje przede wszystkim ich rola pośredniczenia w kontaktach między ludźmi a Bogiem, a także funkcja gloryfikacji Stworzyciela. W takim właśnie kontekście psalm 98 (Psalterz złożony, s. 97) wspomina o ich istnieniu. Podobnie psalm 102 nawołuje „Błogosławcie Pana, wszyscy Jego aniołowie, możni potęgą, pełniący Jego rozkazy, słuchający głosu Jego słów" (Psałterz złożo$n y$, s. 110), a 148 uchyla rąbka tajemnicy na temat struktur i hierarchizacji aniołów: „Chwalcie Pana z niebios, chwalcie Go na wysokościach. Chwalcie Go, wszyscy Jego aniołowie, chwalcie Go, wszystkie Jego moce" (Psałterz złożony, s. 142). Także śpiewana w Cerkwi stichira psalmów na święto Wniebowstąpienia Pana Naszego Jezusa Chrystusa, wspomina o roli świata niewidzialnego w wywyższeniu Pana: „Wstępuje Bóg wśród radosnych okrzyków, Pan przy dźwięku trąby. Wstąpił na cherubiny i uleciał, uleciał na skrzydłach wiatru (...). Pokłońcie się Mu wszyscy Jego aniołowie. Bóg zasiada na świętym swoim tronie (...)" (Psalterz złożony, s. 179). Dlatego też Cerkiew - świadoma roli, jaką ogrywa świat niewidzialny - nie zapomina o świętych bezcielesnych i wspomina ich także w swoim kalendarzu liturgicznym (Psałterz złożony, s. 184) ${ }^{8}$, nie

\footnotetext{
6 Kościół Wschodni za zbiór dogmatów uznaje Niceo-Konstantynopolitańskie Wyznanie Wiary, w którym brak jest spornego dopisku „filioque” świadczącego o pochodzeniu Ducha Świętego od Ojca przez Syna. W artykule przyjmuje się teologię dogmatyczną Kościoła Wschodniego.

${ }^{7}$ „Któż tedy ośmieli się sądzić, że aniołowie zostali stworzeni po tym wszystkim, co wyliczono w związku z sześciu dniami? Lecz choćby nawet znalazł się ktoś tak nierozsądny, to jego błędnemu mniemaniu daje odpór mająca tę samą powagę wzmianka w Piśmie, gdzie Bóg powiada: «Gdy stworzone zostały gwiazdy, głosem wielkim chwalili mnie wszyscy aniołowie moi». A zatem aniołowie już istnieli wtedy, gdy zostały stworzone gwiazdy. Gwiazdy zaś stworzył Bóg czwartego dnia. (...) Nie ulega więc wątpliwości, że jeśli aniołowie należą do dokonanych przez Boga w sześciu dniach dzieł, to są oni owym światłem, które otrzymało nazwę dnia" - pisał św. Augustyn.

8 Na wspomnienie świętych mocy bezcielesnych, chór śpiewa w Cerkwi:
}

zapominając o ich obecności i stałym miejscu w Bożym dziele całego Stworzenia.

Świat niewidzialny już w perspektywie starotestamentowej zaświadcza o Planie Bożym dotyczącym zbawienia rodu ludzkiego. Pierwszym więc elementem medialności Zbawiciela jest jego mocne umiejscowienie w proroctwach Starego Testamentu i oczekiwaniach Narodu Wybranego. $\mathrm{Na}$ Mesjasza czekano. O Mesjaszu chciano słuchać. Ważne też było to, kto niósł nowinę: Pismo i aniołowie. Już samo to wystarczało, by Świętą Rodzina była w centrum uwagi. Dodajmy do tego jeszcze narodziny nowej gwiazdy, która wbrew prawom natury raz sie przemieszcza, raz staje bez ruchu i słowa trzech królów-magów byśmy mieli idealny „medialny show”. To nie mogło przejść niezauważenie.

\section{Nauka a Wiara}

Spójrzmy teraz na narodziny Zbawiciela także przez pryzmat historyczny i kulturowy, gdyż z tego punktu widzenia również natrafimy na elementy medialności. Wydarzenie betlejemskie poprzedzone było bowiem pojawieniem się na niebie gwiazdy, którą każdy mógł dostrzec, posługując się nawet „niedoskonałą” techniką astronomiczną sprzed dwóch tysięcy lat. Jest to fakt niepodważalny, o którym mówią także współcześni astronomowie. Ewangelista Mateusz relacjonuje to zjawisko tak: magowie, spostrzegli, że „gwiazda, którą widzieli wschodzącą, szła przed nimi, aż stanęła nad miejscem, w którym było Dziecko", któremu złożyli hołd. (Mt 2, 1-11) Dziś wiemy, że od czasu, kiedy gwiazda stała się widoczna dla człowieka „gołym okiem”, aż do momentu dotarcia magów do dzieciątka, mogły minąc nawet dwa lata. Nie zmiana to jednak faktu, że już wówczas obeznani z astronomią uczeni - a wielu wskazuje na to, że owymi magami byli właśnie uczeni astronomowie - mogli zdawać sobie strawę z wagi tego wydarzenia, a w związku z tym wiedzieć, czyje narodziny ona zapowiada. Apostoł Mateusz pisze również, że nawet „,...)Tedy Herod wezwawszy potajemnie Mędrców, pilnie się wywiadował od nich czasu gwiazdy, która się im ukazała" (Mt 2,7). Współcześni naukowcy wiążą opisywane przez św. Mateusza zdarzenie astronomiczne $\mathrm{z}$ wydarzeniem mającym miejsce $\mathrm{w} 7$ r. p.n.e., kiedy to w układzie planet trzykrotnie wystąpiła $\mathrm{w}$ gwiaz-

Uwielbiamy was, archaniołowie $i$ aniołowie, $i$ wszystkie zastepy, cherubini i serafini, sławiacy Pana. Uwielbiamy was, archaniołowie $i$ aniołowie, księstwa, cnoty, trony, panowania, potęi i cherubini, budzacy bojaźń serafini, wysławiajacy Pana. Także ten sam chór śpiewa stichosy psalmów: Wystawiać będę Ciebie, Panie, całym moim sercem i przed aniołami Tobie zaśpiewam. Czynisz Twymi posłańcami duchy i swymi stugami płomienie ognia. Błogosławcie Pana wszyscy Jego aniołowie. Błogosławcie Pana wszystkie Jego moce. Pokłońcie się Mu wszyscy Jego aniołowie. Który zasiadasz na cherubinach, objaw się! Anioł Pański zakłada obóz warowny wokót lękajacych się Jego. Stowem Pańskim umocnione sa niebiosa $i$ tchnieniem Jego ust cata ich moc. Wstapil na cherubiny i uleciat. Chwata i dostojeństwem Go ukoronowałeś. Chwalcie Pana z niebios, chwalcie Go na wysokościach. Chwalcie Go, wszyscy Jego aniołowie. Chwalcie Go, wszystkie Jego moce. Wszystko, co oddycha, niechaj chwali Pana. Chwała, i teraz. Alleluja. Alleluja. Alleluja, chwała Tobie, Boże. (tłumaczenie: ks. Henryk Paprocki). 
dozbiorze Ryb potrójna koniunkcja Jowisza i Saturna. Nie jest to bez znaczenia, gdyż właśnie gwiazdozbiór ten był zawsze kojarzony przez astrologów z Żydami, oczekującymi - jak wiemy - na przyjście Mesjasza (Włodarczyk, 2005). Wschodni mędrcy (królowie, astronomowie), jak również Herod, nie tylko musieli więc zdawać sobie sprawę z wagi zachodzącego zjawiska, ale również - jak to miało miejsce w przypadku magów - zapragnęli wziąć w nim czynny udział. Wyruszyli więc w drogę, by pokłonić się narodzonemu, a później przekazać nowinę swym poddanym. Tak informacja o narodzinach Zbawiciela uzyskuje międzynarodowy, a także polityczny wymiar, gdyż wizyta mędrców w Jerozolimie spowodowała, że miejscowe władze musiały się do niej ustosunkować. Herod zwołuje ,posiedzenie rządu poszerzone o spotkanie episkopatu" (Mt 2 3-5). Późniejsza jego decyzja o przelaniu krwi świadczy również o tym, że wydarzenia tego nie można było po prostu zlekceważyć.

Święta Rodzina, mimo niebezpieczeństwa, nie opuszcza jednak Betlejem od razu po narodzinach. Pozostaje tu dość długi czas. Pamiętamy, że jest to okres spisu powszechnego (Lewandowski, 2010), (Łk 2,1-2). Do miasta przybywają wciąż nowi i nowi ludzie, którzy dzięki temu dowiadują się od pasterzy o narodzinach. Informacja rozchodzi się dalej w świat. Święta Rodzina udaje się następnie do Jerozolimy, gdzie w trakcie obrzezania w świątyni Jerozolimskiej dochodzi do - kolejnego istotnego z punktu widzenia naszego tematu wydarzenia - Spotkania Pańskiego z prorokinią Anną oraz sędziwym prorokiem, św. Symeonem (Łk 2,21), który - według zaświadczeń kościelnej tradycji - tłumacząc w młodości (prawdopodobnie na polecenie faraona) Pismo Starego Testamentu (księgę proroka Izajasza) z hebrajskiego na grekę dla egipskich Żydów, miał wątpliwości co do prawidłowości zapisu „oto panna pocznie i porodzi syna (Iż 7,14). Słowo panna dla Hebrajczyków było równoznaczne z dziewicą, wszak za nierząd karano śmiercią. Symeon postanowił zamienić słowo „panna” na „pani”. Powstrzymał go anioł. Nakazał dokonać tłumaczenia zgodnie z literą pisma i przepowiedział mu, iż nie umrze dopóki nie zobaczy wypełnienia się tych słów.

$\mathrm{Na}$ ikonie Spotkania Pańskiego, będącej jednym z najbardziej popularnych przedstawień tego wydarzenia, w centralnym miejscu widzimy świętą rodzinę, Józefa i Maryję, podającą dzieciątko blisko 300-letniemu Symeonowi stojącemu przed nią na podwyższeniu symbolizującym ołtarz i zarazem ofiarę. Tuż za nim stoi 80-letnia Anna (Łk 2,29-32). To pierwszy element medialności - spotkanie $\mathrm{z}$ najstarszym człowiekiem $\mathrm{w}$ danych czasach, o którym wszyscy mówią, że jest prorokiem. To właśnie on, a nie jeden z wielu kapłanów daje świadectwo o Jezusie. Czyni to w najważniejszym dla Hebrajczyków miejscu - świątyni, gdzie zawsze zbierały się tłumy. Jeszcze bardziej medialnym - zauważalnym i komentowanym - był fakt, że po powrocie z tego spotkania Symeon zmarł.

Jeśli przyjrzymy się także drugiemu, rzadko spotykanemu typowi ikony przedstawiającej to samo wydarzenie, zauważymy znaczące dla naszego tematu obrazowania. Zostały tu umieszczone dodatkowe sceny, które umiejscawiają owo wydarzenie w ciągu historycznym, podkreślając jego znaczenie w ekonomii zbawienia całego człowieczeństwa (Evdokimov, 1986, s. 114-118). Na jednaj ze scen widzimy więc anioła z krzyżem symbolizującym przyszłą mękę pańską, w kolejnej scenie - wspominany wyżej prorok Izajasz, zapisujący na zwojach cudowne poczęcie, a następnej - czeluści otchłani wraz z demonami i zmarłymi wychodzącymi z piekieł, umieszczeni tu na znak mającego nastąpić zstąpienia Jezusa do otchłani po ukrzyżowaniu i - w konsekwencji - odkupienia całego rodzaju ludzkiego. U góry ikony widnieje natomiast symbol scalającej wszystko Trójcy Świętej. Nieprzypadkowo, gdyż właśnie cała Trójca Święta, wszystkie trzy hipostazy biorą udział w procesie medialności. Zanim jednak dojdziemy do Trójcy Świętej, pozostańmy jeszcze na moment przy prorokach.

Postać św. Symeona jest znacząca, gdyż z jednej strony symbolizuje uczonego w Piśmie, a z drugiej - proroka. Jako uczony, przepisując Pismo opierał się na racjonalnych przesłankach logiki, dlatego nie był w stanie pojąć Prawdy Bożej, iż dziewica zrodzi Zbawiciela i chciał zniekształcić przekazywaną światu treść na „logiczną i racjonalną nieprawdę", za co Bóg zatrzymał go przy życiu na ziemi aż do czasu, kiedy będzie sam mógł zaświadczyć o Prawdzie. Jak czytamy z relacji apostoła Łukasza, kiedy starzec ujrzał świętą rodzinę, wziął na ręce dziecko i wypowiedział prorocze słowa: „Oto ten przeznaczony jest, aby przezeń upadło i powstało wielu w Izraelu, i aby był znakiem, któremu się sprzeciwiać będą" (Łk 2,34). Wygłasza także prorocze słowa do Maryi, przewidując również Jej mękę: „Także Twoją własną duszę przeniknie miecz” (Łk 2,34). Starzec przemawia więc teraz słowami Boga tak, jak Stworzyciel sobie tego życzy. To czyni z niego proroka. Od czasów starotestamentowych prorocy byli tymi, poprzez których przemawiał Bóg. Nic więc dziwnego, że ludzi lgnęli do nich, chcieli ich słuchać. Naturalnie więc pojawiało się także wielu uzurpatorów szukających splendoru i chwały. Tymczasem, nie zapominajmy o tym, iż w omawianym czasie w Jerozolimie, na co wskazuje ewangelista Łukasz, przebywało mnóstwo pielgrzymów (Łk 2,22-38), a także - jak wiemy z relacji historyków - cała masa mówców pragnących zaistnieć, bądź jako mesjasze, bądź jako charyzmatycy porywający za sobą tłum. Słowa głoszone publiczności musiały więc zainteresować słuchacza. Można pokusić się o tezę, że słowa o narodzinach Jezusa wywarły znacznie większy wpływ na masy, niż słowa innych oratorów, ponieważ ,przebiły” się spośród wielu innych. Musimy się więc zgodzić, że Boże Narodzenie nie tylko było początkiem publicznego nauczania i aktem tak bardzo medialnym, że wyłącznie Zmartwychwstanie Pańskie mogło mu dorównać. Niemniej jednak sam Jezus także posłużył się „klasycznymi” starotestamentowymi formami prorockimi w głoszeniu prawdy. Był jednocześnie Synem człowieczym i Synem Bożym. I tu dotykamy problemu nurtującego teologów od wieków, mianowicie dwóch natur Zbawiciela. 


\section{Dwie natury Jezusa}

Wspaniałą ilustracja dla naszych rozważań w tym względzie będzie chrzest Pański w rzece Jordan, od którego to wydarzenia uznaje się powszechnie rozpoczęcie tzw. publicznej działalności Jezusa Chrystusa. Chrztu dokonuje św. Jan - nieprzypadkowo - na oczach thumu zebranych ludzi (Mt 3, 13-17; Mk 1, 9; Łk 3, 21-22; J 1,26-34), którzy przybyli tam, by obmyć się w wodzie na znak odpuszczenia grzechów (Mk 1, 4-13). Jest to istotnie pierwszy moment pojawienia się Jezusa Chrystusa (Paciorek, 2008, s. 203) jawnie w takiej roli, jeśli przyjmiemy, iż za publiczne uznajemy to, co potocznie przyszło nam przez to sformułowanie rozumieć (Paprocki, Hryniewicz, Karol, 2010, s. 10; Batut, 2006, s. 9-20)9. Zbawiciel, na oczach zebranego przy rzece thumu, od razu przedstawia się tutaj jako Nauczyciel; ten, za którym mają podążyć inni i który - według słów ewangelisty Jana - jest Dobrym Pasterzem (J 10, 11-18), znającym swoje owce i oddającym za nie swe życie (Twardy, 2007, t. 40, s. 50-64).

Zanalizujmy zatem ten moment pod kątem jednego $\mathrm{z}$ najczęściej podawanych $\mathrm{w}$ tym kontekście teologicznych zagadnień, mianowicie argumentu dotyczącego boskiej i ludzkiej natury Zbawiciela. Żaden z relacjonujących to zdarzenie ewangelistów nigdzie nie wskazuje na to, by Jezus Chrystus - jako wcielony Bóg - musiał obmywać się ze swych grzechów. Wręcz przeciwnie, większość podkreśla bezgrzeszność swego Nauczyciela i Zbawiciela. Spośród licznych fragmentów Pisma Świętego, przywołajmy tutaj ten, w którym Jezus - mówiąc sam o sobie podczas rozmowy z Żydami - pyta: „Kto z was dowiedzie na mnie grzechu? $(\mathrm{J} 8,46)$. Z kolei apostoł Piotr, za prorokiem Izajaszem, przytacza o Jezusie: „(...) nieprawości nie uczynił ani zdrady nie było w ustach jego" (Iz 53,9). Podobnie na temat bezgrzeszności Jezusa wypowiada się ten, z którego rąk Jezus przyjmuje chrzest, sam św. Jan Chrzciciel mówiąc: „(..) wiecie, iż się okazał, aby grzechy nasze zgładził, a grzechu w nim nie masz" (J 3,5). W innym miejscu, także u apostoła Jana, czytamy inne prorocze słowa św. Jana Chrzciciela wypowiedziane podczas opisywanego wydarzenia nad rzeką Jordan: „,...) nazajutrz ujrzał Jan Jezusa idącego do siebie, i rzekł: Oto Baranek Boży, oto który gładzi grzech świata” (J 1,29). Z tego względu św. Jan, czując się niegodnym ochrzczenia Jezusa, mówi o Nim: „Ten, któremu nie jestem godny wiązać rzemyków u Jego sandałów" (J 1,27).

Podobnych przykładów w Piśmie Świętym znajdziemy więcej. Zachodzi więc pytanie: dlaczego Jezus, Syn Boży, Bóg-Człowiek, druga Osoba Trójcy Świętej, ,jedyny bezgrzeszny" 10 także przyjmuje chrzest, jak wszyscy

\footnotetext{
9 Nie chodzi tu o odczytanie chrztu jako momentu otrzymania przez Jezusa pełni Ducha Świętego, a więc i pełni Boskości. Przyjmuje się w artykule teologię dogmatyczną Ojców Kościoła Wschodniego o dwoistości natur Jezusa - boskiej i ludzkiej, w której każda była równie pełna.

10 Patrz: m.in. Stichira Paschy śpiewana podczas całego okresu wielkopostnego, która brzmi: , Woskresienije Christowo widiewsze, pokłonimsia swiatomu Hospodu Iisusu, jedinomu biezhresznomu (...)”, za: liturgia. cerkiew.pl.
}

inni grzesznicy, o którym sam nauczał, iż jest on znakiem obmycia z grzechów: „I byli chrzczeni przez niego w Jordanie, spowiadając się z grzechów swoich" (Mt 7, 6-7). Odpowiedzi padają już w samym Piśmie: aby czynem tym podkreślić ogromne uniżenie, jakiego Bóg - poprzez Drugą Osobę w Trójcy Świętej - dokonał wobec człowieka, poprzez wcielenie i przyjęcie na siebie tej samej co on natury; $\mathrm{tj}$. natury człowieka upadłego. Co za tym idzie wszystkie konsekwencje grzechu pierworodnego, tj. wszelkie namiętności ${ }^{11}$ (takie jak gniew itp.), cielesności (tj. senność, głód, zmęczenie), czy wreszcie śmiertelności, Jezus, jako Bóg-Syn, druga hipostaza Trójcy Świętej, poprzez wcielenie przyjął na siebie. Stał się tym, czym my, za wyjątkiem grzechu. Był człowiekiem z jego słabościami, ale jednocześnie był także Bogiem (Evdokimov, 1986; Łosski, 1989; Meyendorff, 2007) ${ }^{12}$.

Dwie natury Jezusa Chrystusa, boska i ludzka oraz ich wzajemne relacje były często osią sporów wielu teologów (Hrycuniak, 2003). Jednym z głosów, jakie podnoszono, była wątpliwość dotycząca człowieczeństwa Jezusa, który - będąc Bogiem - był jednocześnie człowiekiem, a więc doświadczał ludzkich namiętności, ponieważ grzeszność stała się chorobą, integralną częścią natury upadłego człowieka (nie na zasadzie genezy, a nabycia). Ukazuje to chociażby sytuacja w świątyni, gdy Jezus - widząc handlujący w Domu Bożym tłum - ulega napadom gniewu, którego nawet nie skrywa, ale jawnie okazuje handlującym w świątyni, o czym zaświadcza ewangelista Jan pisząc o tym wydarzeniu tak: „I wszedł Jezus do świątyni Bożej i wyrzucał wszystkich sprzedających i kupujących w świątyni, a stoły bankierów i ławki sprzedających gołębie poprzewracał" $(\mathrm{J} 21,12)^{13}$. Spory na temat tego, kim w rzeczywistości był Jezus Chrystus, toczono przez okres pierwszych Soborów Powszechnych. Zakończono je jednoznacznym uznaniem integralności dwóch natur, wraz z dogmatem o boskości Jezusa, Syna Boga, Drugiej Osoby Trójcy Świętej (Meyendorff, 2007). Dogmatyczna teologia Kościoła Wschodniego opiera się na wierze w unię hipostatyczną (Evdokimov, 1986, s. 231-233). Zbawiciela, zjednoczenia dwóch natur w jednej osobie Syna Bożego Jezusa Chrystusa, wedle dogmatu chalcedońskiego „bez podziału, bez zlania, zmieszania i bez rozdzielania i rozłączenia".

Postawić może pytanie, skąd wzięły się dylematy, które nurtowały teologów? Odpowiedzią na to pytanie niech będzie ten moment z życia Zbawiciela, w którym oddala się On od swoich uczniów, by udać się samotnie na czterdzieści dni na pustynię. Święty Grzegorz Wielki, w ewangelicznym opisie kuszenia na pustyni, podkreśla, iż jest to dowód boskości, ale zarazem także i człowieczeństwa Chrystusa. „Chrystus ukazany w tym krótkim wyjaśnieniu

\footnotetext{
Pisząc o konsekwencjach natury człowieka po upadku, mowa o tym, co w tradycji Kościoła Wschodniego nazywane jest przez Ojców ludzkimi namiętnościami, a więc: gniew, żądza władzy, duma, etc. (Św. Paisjusz Hagioryta 2012; Nikołaj Serbski, 2008)

12 Przyjmuje się w tej pracy założenia dogmatyczne antropologii Kościoła Wschodniego.

13 Należy zaznaczyć, że gniew nie musi być oczywiście pojmowany jako grzech. Apostoł Paweł w liście do Efezjan (4, 26) wzywa: ,,(...)gniewajcie się ale nie grzeszcie".
} 
jest takim, jakim Go widział Sobór w Efezie - prawdziwym Bogiem i prawdziwym Człowiekiem (Lachowicz, 1994, s. 171).

W tym miejscu, pozwolę sobie na małą uwagę. Mimo iż dogmat tyrynitarności omówię dokładniej poniżej, to już w tym miejscu rozważań chcę podkreślić, że Chrystus jest prawdziwym Bogiem. Drugą Osobą Trójcy Świętej, Synem Boga, i jako taki, jest między innymi istotą całkowicie duchową, niepoznawalną, niedostępną, by nie powiedzieć - dla większości ludzi - niedoświadczalną. Bóg -Ojciec, pragnąc ukazać ludziom swą obecność, zjawiał się Mojżeszowi jako gorejący krzew (Wj 3,1-18), Izraelitom uciekającym z Egiptu objawił się jako słup ognia i dymu (Wj 13,17-22). Syn „używa” wcielenia. Można więc uznać Wielenie za najdoskonalszy przejaw medialności Zbawiciela. To dzięki niemu Pan może prowadzić Swą działalność, głosić przypowieści, świecić przykładem, potwierdzać słowa uzdrowieniami i cudami.

Rozwijając w tym kontekście temat owej pracy, uznaję, że znaczenie medialności, którą „wypełnił” Bóg-Syn, należy rozumieć szerzej niż wyłącznie poprzez Jego publiczną działalność. Głównie poprzez odwołanie się do dwoistości Jego natur, w tym przypadku natury Boskiej, którą - w znaczeniu medialności - rozumiem, jako pośrednictwo, relacje między ludem, a Bogiem ${ }^{14}$. Nie neguję i nie umniejszam też ludzkiej natury. Skoro to ludzie byli odbiorcami zwiastowania to któż, jeśli nie człowiek lepiej im o tym opowie.

\section{Prorocy. Historia. Kontynuacja}

Według tradycji biblijnych, termin prorok stosowano na określenie mówców, którzy - jak wskazuje Pismo - zostali posłani przez Pana, by w Jego imieniu głosić Słowo Boże. O piśmiennictwie biblijnych proroków w powyższym kontekście praktycznie nie może być mowy. Nie oznacza to oczywiście, że pomijam całkowicie takie aspekty medialności naszego Zbawiciela, jak: stosowanie niespotykanych wcześniej form oratorskich, czy też wykorzystywanie specyficznych form „mównic” jak góry, jeziora i rzeki, czy wzgórza, z których głos przemawiającego Chrystusa głoszącego Słowo Boże roznosił się do wszystkich, którzy tylko zechcieli słuchać. W Starym Testamencie napotkamy często na podobne zabiegi, nie zmienia to jednak faktu, iż także w tym przypadku zabieg okazał się być niezwykle skutecznym, co widać w opisie Kazania na Górze (Mt 5,1-7,28; Łk 6,17-49). Także woda sprawdziła się w roli mównicy. Jak wiadomo, przez wodę dźwięk rozchodzi się znaczenie szybciej i donośniej niż po powietrzu, dlatego w licznych miejscach Ewangelii natrafiamy na fragmenty, w których Nauczyciel wchodzi

\footnotetext{
14 Oczywiście należy pamiętać o ekonomii zbawienia, odkupienia oraz przywrócenia poprzez Wcielenie i Zmartwychwstanie Zbawiciela możliwości ponownego jednoczenia się człowieka z Bogiem, które utracił on wskutek grzechu prarodziców, a którego konsekwencje dziedziczymy jako ich potomkowie.
}

do łodzi i ze środka jeziora naucza zgromadzonych przy brzegu słuchaczy. Przykładów znajdziemy w Piśmie wiele. Nie sposób przytoczyć wszystkich, posłużmy się zatem dwoma. Pierwszy, autorstwa apostoła Mateusza: „Owego dnia wyszedłszy Jezus z domu, siedział nad morzem. I zebrały się przy nim rzesze wielkie tak, że wstąpiwszy do łodzi, siedział, a cała rzesza stała na brzegu. I powiedział im wiele w przypowieściach (...)" (Mt 13,1-3). Z kolei inny ewangelistów, św. Marek podaje: „I począł znowu uczyć przy morzu; i zebrała się koło niego rzesza wielka, tak że wszedłszy do łodzi, siedział na morzu, a wszystka rzesza była przy morzu na ziemi. I nauczał ich wiele w przypowieściach, i mówił im w nauce swojej" (Mk 4,1-2). Woda czyniła z Chrystusa ,jedynego mówcę”, ustawiała go niejako na wielkiej scenie, gdzie nic i nikt nie odciągał od Niego uwagi odbiorców.

Nie można oczywiście nie uwzględnić także samej formy oratorsko-językowej, w jakiej Jezus przemawiał do ludu. Nie były to słowa, do jakich przyzwyczajeni byli potomkowie Narodu Wybranego. O przypowieściach jezusowych napisano już tak wiele, że nie jest koniecznym, by w tej pracy powielać treści. Warto nadmienić, iż pytanie dlaczego Chrystus przemawia w sposób tak niecodzienny dla współczesnych - zadali swemu Nauczycielowi sami Jego uczniowie. Nauczyciel objaśnił to od razu, nie ukrywając niczego przed nimi. „A gdy był sam tylko, spytało go o przypowieść tych dwunastu, co przy nim byli. I mówił im: Wam dane jest poznać tajemnicę królestwa Bożego; ale tym, którzy są zewnątrz, wszystko dzieje się w przypowieściach, aby patrząc patrzyli, a nie widzieli, i słysząc słyszeli, a nie zrozumieli, by się kiedy nie nawrócili, a nie były im odpuszczone grzechy" (Mk 4,10-12). Zostawmy zatem na boku wątki, które rozwiązał już sam Chrystus, i zwróćmy się w stronę zagadnień związanych z tematem pracy, które wymagają dłuższej analizy, a które będą stanowiły trzon dalszych rozważań.

Już w opisywanym we wstępie pierwszym publicznym wydarzeniu z udziałem Jezusa (w Bożym Narodzeniu Zbawiciel jest „,biernym” sprawcą zwiastowania Ewangelii), w trakcie chrztu Pańskiego w Jordanie, ukazuje się On jako Nauczyciel. Z tego względu, jak podkreślają Święci Ojcowie ${ }^{15}$, Jezus swym chrztem naucza dzieci Boże, daje im przykład, jak mają czynić, jaką ścieżką iść, jaki cel obrać w drodze do zbawienia, ponieważ - jak sam często podkreśla - i w tym celu został posłany przez Ojca; „A on im rzekł że potrzeba, abym i innym miastom opowiadał królestwo Boże; bo na to jestem posłany" (Łk 4,43). Później w niekończącym się sporze z faryzeuszami,

15 O Jezusie Chrystusie i Jego wcieleniu jako Drugiej hipostazie Trójcy dyskutowano i toczono spory niemalże przez cały okres Soborów Powszechnych. Nie jest celem tej pracy przytaczanie całości historycznych dociekań. Pominięta zostanie zatem całość konstytuowania się symboli wiary i wszelkich dogmatycznych problemów z tym związanych. Zaznaczając jednocześnie na wstępie tej pracy przyjęcie perspektywy Świętych Ojców Kościoła Wschodniego, wydaje się oczywiste, że odnośnie nauki o Trójcy Świętej konsekwentnie kontynuuje się prawosławne pojmowanie Św. Trójcy (Kuryś, 2001) oraz pisma Ojców (m.in.: Św. Bazyli Wielki, 1972; Św. Cyryl Jerozolimski, 1973; Św. Jan Damasceński, 1969). 
powie tak: „Ale wy nie dajcie się nazywać: rabbi; albowiem jeden jest nauczyciel wasz, a wy wszyscy braćmi jesteście" (Mt 23,8).

Bardzo ważnym jest, że w tym momencie także po raz pierwszy Bóg ukazuje się nam w Trójcy Świętej; dowiadujemy się o Duchu Świętym, a z nieba słyszymy, kim naprawdę jest Jezus: „To jest mój Syn umilowany, w którym mam upodobanie, Jego słuchajcie!” (Mt 17,1-9). Wróćmy teraz do wydarzenia Bożego Narodzenia. Akcentowaliśmy, że jest to „bierne” zwiastowanie samą swą obecnością. Tam więcej mówiła przyroda i siły niebios niż rodzący się Mesjasz. Nad Jordanem mamy ten sam rodzaj medialności. Jezus zachęca Jana do ochrzczenia Go, choć tego nie potrzebowa $1^{16}$. Podporządkowując się prawom oczyszczenia (chrztu) zaświadcza tym samym o swym człowieczeństwie. Głosi: jestem takim człowiekiem jak wy. Jednocześnie o Jego boskości zaświadczają: przemawiający z niebios Bóg Ojciec, zstępujący na Niego Duch Święty, a także św. Jan Chrzciciel.

Tak więc, ten to Nauczyciel, Bóg-Syn, jako jedyny łączący dwie natury głosi Słowo Boże, które - należy podkreślić - przejawia się z Jego drugiej natury, natury boskiej. Medialność Jezusa łączy zatem Jego Boskość z Jego człowieczeństwem i objawia grzesznej ludzkości to, co chce im powiedzieć Bóg, by ich zbawić, wyrwać z letargu, kłamstwa i grzechu. Jak mówi proroctwo Izajasza, życie Jezusa „prowadzi przez cierpienie do chwały” (Iz 53,1-12). Czas Starego Przymierza i proroków starotestamentowych kończy się wraz z początkiem działalności Jezusa. Teraz „Jego słuchajcie” (Łk 9, 35), jak mówi Bóg tym razem w relacji apostoła Łukasza - (por. Pwt 18,5). Jezus jednakowoż dookreśla swoje posłannictwo, nauczając: „Nie przyszedłem znieść prawa proroków, ale je wypełnić" (Mt 5,17).

A zatem, Bóg-Syn, mesjasz, prorok, nauczyciel - to w tych aspektach w moim odczuciu rozpatrywać należy istotę medialności Jezusa, który począwszy od omawianego wydarzenia, poprzez kolejne trzy lata będzie ,z woli Boga” wypełniać Pismo, w którym napisano: „A na koniec posłał do nich syna swego, mówiąc: Uszanują syna mego. Lecz oracze ujrzawszy syna, mówili między sobą: Ten jest dziedzic, pójdźcie, zabijmy go i posiądziemy dziedzictwo jego. I pojmawszy go, wyrzucili z winnicy i zabili” (Mt 22,33-46). A w innym miejscu: „Przyszedł do swoich a swoi go nie przyjęli" (J 1,11). Tak samo więc, jak owi dzierżawcy winnicy, którzy - mówiąc przypowieścią Jezusa - nie chcą, by im przypominano o tym, kto jest właścicielem winnicy, kim jest ich Pan i jak należy postępować, chcą - pogrążeni w samowoli - zapomnieć o Jego istnieniu, zgładzić sługi Jego i Syna Jego, tak też tenże lud nie chce przyjąć słów proroków, ani nauk Jezusa. Powód?

\footnotetext{
16 Zbawicie przystępuje do chrztu nie po to by oczyścić się wodą (skoro już jest oczyszczony boskim duchem - jest Bogiem, a po to by swą boskością uświęcić i oczyścić wodę dając jej moc oczyszczania. Zbawiciel ,chrzci wodę”.
}

\section{Medialność - jestem tym którego potrzebujecie}

Dlaczego głoszenie Słowa Bożego wiązało się z cierpieniem? Co takiego mówił Jezus, co głosili apostołowie i prorocy, że byli za swoje słowa szykanowani, znieważani przez kapłanów szkolonych w Piśmie, a nawet skazywani na śmierć? Odpowiedź znajdziemy w Piśmie. Była to Prawda, która odzierała z kłamstwa i ułudy (J 16,5-15), która grzesznym i brudnym nie dawała możliwości spokojnie chować się w mroku. Taka prawda i droga, które wymuszały konieczność zmiany dotychczasowych paradygmatów oraz przemianę (gr. metanoia), jaka dokonywała się po przyjęciu Słowa Bożego (Evdokimov, 1986, s. 63). Taką funkcję na proroków nakładał sam Bóg. Mieli oni nie tylko głosić Jego wolę, ale - co ważniejsze - sprawić, by poprzez słowa, jakie w imieniu Pana przekazują, zmieniły się dotychczasowe wartości człowieka. Niewyobrażalne dla wielu są zalecenia Jezusa: „Kto kocha ojca lub matkę bardziej niż mnie nie jest mnie wart" (Mt 10,3742), kochajcie wrogów waszych, dobrze czyńcie tym, którzy was nienawidzą, błogosławcie tym, którzy was przeklinają, i módlcie się za tych, którzy was oczerniają ( $\mathrm{kk}$ 6,27-18). Kim jest Ten, który przemawia w taki sposób? Pytanie to często zadawali ludzie, którym dane było słuchać słów Jezusa. Dziś możemy im odpowiedzieć: Jest nim Ten, któremu w swoim ziemskim życiu jesteś winien więcej, niż ziemskim rodzicom, dzięki któremu otrzymasz życie wieczne. „Jam jest Drogą, Prawdą i Życiem. Nikt nie przychodzi do Ojca inaczej jak tylko przeze Mnie. Gdybyście Mnie poznali, znalibyście i mojego Ojca. (J 14,7). Także słuchający Jezusa podczas Kazania na Górze, w którym nauczał On zebrany lud o nieznanych im dotąd błogosławieństwach Bożych, odczuwają, iż: „Nikt jeszcze nie przemawiał tak, jak ten człowiek” (por J 7,46). Jest to oszałamiająca zmiana w umysłach i sercach ludzkich stworzeń. Nic więc dziwnego, że sam Nauczyciel zwykł znamiennie rozpoczynać swe przypowieści frazą: „,mówiono wam, że..., a ja wam powiem, że...”.

Takiej Prawdy Słowa Bożego niejeden przyjąć nie potrafił. Zbyt mocno był przywiązany do dawnych tradycji, do tego co znał, co było sprawdzone i wygodne. Ta więź niejednokrotnie była tak silną, że jedynie cud bądź tragedia mogły ją naderwać. Wiedział o tym Jezus i przekonali się o tym także starotestamentowi prorocy, którzy otrzymywali od Boga liczne dary w jednym celu: by poprowadzić ludzi w odpowiednim kierunku do Boga, wyrwać ich z błędu i kłamstwa, zbłądzenia i grzechu, w jakim żyli dotychczas. $\mathrm{Z}$ takim posłannictwem mało kto zyskiwał sobie przychylność ogółu, przywołajmy chociażby przykład Mojżesza stojącego przed faraonem, Noego, gdy budował arkę, Jana Chrzciciela względem Heroda, itd. Rolę, którą Bóg polecił odegrać prorokom, misja głoszenia Prawdy - Słowa Bożego, musiała wywrzeć ogromny wstrząs w ludziach, dlatego też - jak postaram się wykazać poniżej - większość z proroków nie chciała przyjmować na siebie tak ogromnego trudu, ponieważ rozumieli z jak wielkimi przeciwnościa- 
mi, a nawet nienawiścią przyjdzie się im zmierzyć. Prorok Jonasz, który ucieka przed powierzoną mu misją, nie jest w tym odczuciu osamotniony, o czym dokładniej - poniżej.

Nie każdy wobec tej Prawdy zachowywał się tak, jak Nikodem, przedstawiciel żydowskich dostojników i zarazem faryzeusz, który nie mogąc pojąć nauki Chrystusa, przychodzi do Niego w nocy, by zadać pytania i zrozumieć to, co było dla niego dotąd niezrozumiałe. Czuje wszakże, że nauka Jezusa wypływa z ust Boga i wbrew opinii pozostałych uczonych w Piśmie wie, że nauka Chrystusa Pismu nie przeczy (Nalewaj, 2011, s. 211-212). Nikodem dostaje od Jezusa niespotykaną dotąd lekcję, gdy Ten mówi mu o konieczności odrodzenia się z Ducha. Żydowski dostojnik, nie jest w stanie zrozumieć znaczenia słów Zbawiciela i wyjść poza materialne, ziemskie rozumienie sensu słów: „Jeśli się kto nie odrodzi z wody i z Ducha Świętego, nie może wejść do królestwa Bożego. Co się narodziło z ciała, ciałem jest, a co się narodziło z Ducha, duchem jest" (J 3,3-6). Ten dialog wykracza poza rozmowę dwóch osób. Staje się niemalże przełożeniem na dyskusję między Starym a Nowym Testamentem, między nowo rodzącym się Kościołem, a niewierzącymi w Zbawiciela (helleno-judejskim światem), Syna Człowieczego i objawienia w Nim - za pośrednictwem Ducha Świętego - samego Boga. Jednak dla racjonalnie myślącego umysłu sprawy niebiańskie są niedostępne. A co za tym idzie, także niemożliwe jest: ujrzenie „w Duchu uwielbionego Chrystusa”, zapowiadane w Starym Testamencie wywyższenie Syna Człowieczego, ani dokonanie się w Nim planu Bożego (Nalewaj, 2011, s. 216). Nawet Apostołom jeszcze nie przekazano tej nauki.

Na tym przykładzie widać, że po zetknięciu się z nauką Jezusa, wysłuchaniu Słowa Bożego, człowiek głębokiej wiary nie może pozostać obojętny, bo otwarcie na prawdziwego i żywego Boga zmienia cały dotychczasowy świat człowieka, który wcześniej bez Niego błądził. Wkroczenie na ścieżki, które On wyznacza, musi odbyć się wraz z holistyczną zmianą życia człowieka. Jednak częściej zdarzały się sytuacje, w których ludzie ,słuchali, a nie słyszeli, patrzyli, a nie widzieli”, o czym przekonali się prorocy głoszący Słowo Boże, którzy niejednokrotnie zostawali okrutnie karani za głoszenie - w odczuciu im współczesnych - rewolucyjnych treści, chyba że jak Izajasz zdołali uciec i schronić się w pustyni przed rozgniewanymi słuchaczami. Nigdy wcześniej wypowiedziana prawda nie była tak ciężką dla wielu, zbyt ciężką by w nią uwierzono. Była na tyle trudna do zaakceptowania, że doprowadziła do męczeńskiej śmierci większość apostołów, których Jezus posłał w świat głosić Słowo Boże.

\section{Medialność. Oto posylam was}

Już samo określenie ,posłaniec boży” odsyła do Osoby Tego, który posyła. Zachodzi więc także i tutaj relacja pośrednictwa, medium, które - poprzez Wcielenie Logosu - przybliża ludziom naukę Boga Ojca. Dzieło zbawcze
Chrystusa kontynuowane jest następnie w biblijnym kerygmacie Nowego Testamentu w osobach apostołów, biskupów, nauczycieli, itp. Ci z kolei, nie byliby w stanie nic uczynić (J 15,5), bez pośrednictwa Chrystusa, który posyłając Ducha Świętego ofiarowuje im dar czynienia (woli Boga). Kładzie mocny nacisk, że to nie oni będą mówić, a Duch przemówi przez nich: „A gdy was poprowadzą, żeby was wydać, nie martwcie się przedtem, co macie mówić; ale mówcie to, co wam w owej chwili będzie dane. Bo nie wy będziecie mówić, ale Duch Święty" (Mk 13,11). Rozwój homiletyki kolejnych pokoleń jest kontynuacją głoszenia Słowa Bożego i nakierowaniem chrystologicznym, które - niezależnie od form i możliwości głoszenia uzależnionych od czasów i okoliczności - nosi znamiona medialności.

Wybór Boga, tj. namaszczenie kogoś na apostoła lub proroka zawsze oznaczało dla niego wielki trud i cierpienie. „Staliśmy się jakby odpadami świata” (1 Kor 4,13) - pisze o swym posłannictwie Apostoł Paweł, o którym Bóg - jeszcze jako o oślepionym Szawle - powiedział: „wybrałem go sobie na narzędzie” (Dz 9,10-17), by podobnie, jak inni uczniowie Jezusa wyruszył w świat nawracać niewiernych, bo Jezus „Rozkazał nam głosić ludowi i dać świadectwo" (Dz 10,43) - jak przytacza Apostoł Piotr, mówiąc „Idźcie więc i nauczajcie wszystkie narody” (Mt 28,19). „Oto ja was posyłam jak owce między wilki” (Mt 10,16-23) - mówi Jezus do swych uczniów po zesłaniu na nich Ducha Świętego (Paprocki, 2001, s. 10). Ducha Prawdy, bez którego wcześniej prawdy „znieść nie mogli” (J 16,5-15). Nauczyciel nie ukrywa przed swymi uczniami, że posyła ich na męki, prześladowania i niewyobrażalne cierpienia, o czym świadczą opisy Dziejów Apostolskich - „Powstawszy zaś najwyższy kapłan i wszyscy, co z nim byli, (to jest sekta saduceuszów), przepełnieni zazdrością, pojmali apostołów i wtrącili ich do publicznego więzienia" (Dz 5,16-17). Dlatego św. Nikołaj Serbski konkluduje, że „na krwi apostołów zbudowana jest cerkiew” (Nikołaj Serbski, 2008, s. 117). Zastanawiający jest fakt dlaczego apostołowie, wiedząc jaką zapłatę otrzymają za głoszenie, podjęli się tego dzieła?

Jak opisują dalej Dzieje Apostolskie, ten sam Apostoł Paweł, przemieniony i nawrócony przez Boga oślepiającą mocą boską (Dz 9,1-9), gdy został pojmany z zamiarem zgładzenia - „poruszyło się całe miasto, i zbiegł się lud. A pojmawszy Pawła, wlekli go poza świątynię, i natychmiast zamknięto bramy. Gdy usiłowali go zabić (...)" (Dz 21,27-30) Żydzi domagali się Jego śmierci, a gdy zaczął do nich przemawiać, wręcz ,(...) podnieśli głos swój, mówiąc: Zgładź z ziemi takiego, albowiem on nie powinien żyć. A gdy oni wrzeszczeli, i rzucali swe szaty, i miotali proch w powietrze, rozkazał trybun wprowadzić go do obozu, i biczami chłostać, i męczyć go, żeby się dowiedzieć, dla jakiej przyczyny tak nań krzyczeli” (Dz 24). Jednak gdy w Aeropagu zaczął nauczać o zmartwychwstaniu, zlekceważono go i wyśmiano. Jak sam wspomina: „Przez Żydów pięciokrotnie byłem bity po czterdzieści razów bez jednego. Trzy razy byłem sieczony rózgami, raz kamienowany, trzykrotnie byłem rozbitkiem na morzu, przez 
dzień i noc przebywałem na głębinie morskiej. Często w podróżach, w niebezpieczeństwach na rzekach, w niebezpieczeństwach od zbójców, w niebezpieczeństwach od własnego narodu, w niebezpieczeństwach od pogan, w niebezpieczeństwach $\mathrm{w}$ mieście, $\mathrm{w}$ niebezpieczeństwach na pustkowiu, w niebezpieczeństwach na morzu, w niebezpieczeństwach od fałszywych braci; w pracy i umęczeniu, często na czuwaniu, w głodzie i pragnieniu, w licznych postach, w zimnie i nagości, nie mówiąc już o mojej codziennej udręce płynącej z troski o wszystkie Kościoły" (2 Kor 11, 24-28).

Jednak nie tylko apostołowie Dobrej Nowiny odczuwali trudy i ciężar posłannictwa Boga. Także niemal żaden z proroków sam z siebie nie chciał podjąć się tej roli. Najwyższy z darów Ducha Świętego, jakim obdarzył ich Bóg, był zbyt wielką udręką. Zarówno Jeremiasz, Izajasz, jak i nawet Mojżesz, nie chcieli i nie zabiegali o niego. Co więcej, gdy go otrzymali, próbowali pertraktować z Bogiem, by oddalił od nich swój zamysł i plan, który mieli wypełnić. Mojżesz w chwili objawienia mówi Bogu, że słabo przemawia. Jeremiasz wątpi w swoje siły, a Jonasz wręcz ucieka przed Bogiem statkiem w daleką podróż. Ogromny i niebywały ciężar, jaki wiązał się z nauczaniem ludów, często bywał zbyt ciężki do udźwignięcia. To krzyż Pański, w obliczu którego nawet Jezus prosi Ojca, by „Ojcze mój, jeśli to być może, niech odejdzie ode mnie ten kielich" (Mt 26, 39).

Niech za najlepszy przykład posłuży tu Jonasz, nie nazywany wprawdzie w Piśmie prorokiem, ale powołany przez Boga do tej roli, takimi oto słowami: „Wstań, a idź do Niniwy, miasta wielkiego i przepowiadaj w nim, bo doszła złość jego przede mnie" (Jon 1,2). Ten jednak zlękniony ucieka przed Bogiem. Boi się wypełnić wolę Boską, nie chce przyjmować na siebie roli posłannika, który ma uświadomić Niniwijczykom ich upadek, grzech i bezprawie, nawołując jednocześnie do zmiany całego życia, poprzez pokutę oddaną Stwórcy. Uznaje siebie za niezdolnego do przyjęcia i wykonania tego zadania. Obawia się reakcji ludu, któremu ma ogłosić, że sposób w jaki żyją jest niemiły Bogu. Choć znając miłosierdzie Boże wie, że Bóg przebaczy Niniwijczykom, ale nie wie, jak lud ten zachowa się wobec proroka nawołującego ich do zawrócenia ze złej drogi. Woli uciec, niż spełnić wolę Boga. Jednak, gdy w trakcie ucieczki wpada do otchłani wód, sam zaczyna kajać się przed nieposłuszeństwem wobec Boga i otrzymuje naukę, że z wyborem Boga nie można walczyć. Przybywa wreszcie do Niniwy i przepowiada ludowi karę Bożą (Jon 1,4), Bóg posyła go do Niniwy, by zwiastował jej zgubę (Jon 1,4). „I począł Jonasz wchodzić do miasta, ile mógł ujść dnia jednego, i wołał mówiąc: Jeszcze czterdzieści dni, a Niniwa będzie zburzona" (Jon 4).

Biblijny Jonasz od zawsze pasjonował egzegetów i znawców Pisma (Bartoszewicz, 2015, s. 195-201). Nie zapominajmy, że prawo starotestamentowe mówiło o karze śmierci dla proroka przemawiającego w imieniu Jahwe, a którego słowo ostatecznie się nie spełni. (Pwt 18,20-22). I choć motyw ,uciekającego proroka" pojawia się wcześniej w Starym Testamencie, chociażby w postaci Eliasza (por. $1 \mathrm{Krl} 19$ ), czy Uriasza (por. Jr 26), to jednak w tej krótkiej Księdze Jonasza zawarta jest nauka, która posłużyła później wielu za przykład. Ani Eliasz, ani Uriasz nie uciekali bowiem przed Bogiem, nie sprzeciwili się Jego woli. Jonasz - owszem. Wydaje mu się, iż taka ucieczka jest możliwa. Dopiero w obliczu katastrofalnego sztormu na morzu przekonuje się, że przed wyrokami i wolą Jahwe nie można uciec. Zamiast tego można zgubić siebie i współtowarzyszy. Świadomość ta staje się źródłem uzmysłowienia sobie i wyznania własnej tożsamości (Zagórski, 2009, s. 116-125): „Jestem Hebrajczykiem i czczę Jahwe, Boga nieba, który stworzył morze i ląd" (Jon 1,9) - przyznaje wreszcie prorok. Czuje jednocześnie nieopisaną potęgę Jahwe. Wie, że wszystko, łącznie z katastrofą, dzieje się z Jego woli. A sztorm jest przejawem gniewu Bożego, wobec nieposłuszeństwa jakiego dopuścił się Jonasz (Bartoszewicz, 2014, s. 195-201).

Mimo tego, w obliczu katastrofy Jonasz nie ucieka z błagalną modlitwą ku Stwórcy, jak zrobili to obecni na statku marynarze, którzy porzucają swoich bogów i zwracają się do „Boga Jonasza”. Prorok podejmuje kolejną próbę ucieczki. Dlaczego? Nie wierzy w siebie. Nie chce podjąć misji wyznaczonej mu przez Boga. Woli umrzeć, prosi o wyrzucenie go za burtę z nadzieję, że „uspokoi” Boga swoją śmiercią. Jednak Bóg wierzy w niego. Bóg wszakże nigdy się nie myli. Jahwe zsyła mu ,wielką rybę”, która połyka go (Jon 2,1), staje się więzieniem dla proroka, a dokładniej nowym statkiem, który zawiezie go tam gdzie ma głosić wolę bożą. Owo więzienie, wnętrze ryby, to teraz cały wszechświat Jonasza, poza nim niczego innego nie ma. Wnętrze ryby symbolizuje tym samym wszechobecność, wszechwładzę i potęgę Stwórcy, Boga, przed którym nie można uciec.

Istotę $\mathrm{i}$ wagę znaczenia postaci Jonasza poświadcza fakt, iż sam Syn Człowieczy w trakcie swej działalności publicznej, wspomina o nim w swych naukach. Jak to rozumieć? Z jednej strony należy zauważyć łączność historyczną, ciągłość wydarzeń Opatrzności, ,zamysłem Boga” wobec swych stworzeń, do której nawiązuje także Jezus. „Jak bowiem Jonasz był znakiem dla mieszkańców Niniwy, tak będzie Syn Człowieczy dla tego plemienia" (Łk 11,30); „To plemię jest plemieniem przewrotnym. Żąda znaku, ale żaden znak nie będzie mu dany, prócz znaku Jonasza" (Łk 11,29). Z drugiej strony należy oczywiście podkreślić sens proroctwa, które kontynuuje Jezus. Wychodząc od historii i przeszłości, mówi o przyszłości, o tym, co dopiero ma się wydarzyć (Evdokimov, 1986, s. 403-407) ${ }^{17}$. „Albowiem jak Jonasz był trzy dni i trzy noce we wnętrznościach wielkiej ryby, tak Syn Człowieczy będzie trzy dni i trzy noce w łonie ziemi” (Mt 12,38-40). Wątek prototypu Jezusa, jaki upatruje się w Jonaszu, jest często wykorzystywany przez egzegetów, którzy - wskazując na motyw Zmartwychwstania naszego Zbawiciela - odwołują się do dni, w których Jonasz przebywał we wnętrzu ryby. Choć faktycznie - od Ukrzyżowania

\footnotetext{
17 Autor wskazuje, iż teologia historii stawiana jest raczej w porządku teologii wiary, a nie porządku teologii rozumu. Absolutnym podmiotem historii jest Chrystus, jest ,absolutną miarą powszechnego teandryzmu”. Ludzkość, powołując się na Chrystusa, także staje się podmiotem historii.
} 
do Zmartwychwstanie nie upłynęły trzy dni i trzy noce, to jednak, biorąc pod uwagę wierzenia semickie tamtego czasu, od fizycznej śmierci człowieka do prawdziwej jego śmierci, mijało właśnie trzy dni. Fragment ten więc ma znaczenie symboliczne. Niejako na marginesie trzeba tu dodać, że tak jak głoszenie Zbawiciela nie zakończyło się wraz z Jego Wniebowstąpieniem, ale trwa po dziś dzień, tak i posłannictwo Jonasza nie zakończyło się pod Niniwą. Wraca w czasach Zbawiciela stając się ważną figurą proroctw chrystusowych.

Postawa Jonasza nie była odosobniona. Podobnie także inni prorocy Starego Testamentu, m.in. Mojżesz, Eliasz, których trzech wybranych uczniów Jezusa (Piotr, Jan i Jakub) widzi zasiadających po dwóch stronach Jezusa w chwili Jego Przemienienia na Górze Tabor, jako największych proroków i poprzedników Mesjasza, słysząc swe powołanie przez Boga, próbują przeciwstawiać się Bożemu planowi. Z kolei prorok Jeremiasz w chwili, gdy Pan zwraca się do niego słowami: „Pierwej, niźlim cię utworzył w żywocie, znałem cię, i pierwej, niżeliś wyszedł z żywota, poświęciłem cię, i prorokiem między narodami ustanowiłem cię" (Jr 4-6) odpowiada: „I rzekłem: a, a, Panie Boże! oto nie umiem mówić, bom ja jest dziecina!" (Jr 6) (Tomala, 1938, s. 321-323). Jeremiasz zdaje sobie sprawę z wagi daru, który otrzymał. Sam Bóg nie ukrywa przed nim zadania, jakie mu powierza: „Otom cię dziś postawił nad narodami i nad królestwami, abyś wyrywał i burzył, i wytracał i rozwalał, i budował i sadził" (Jr 10). „Albowiem ja uczyniłem cię dziś miastem obronnym i słupem żelaznym i murem miedzianym przeciw wszystkiej ziemi, królom Judy, książętom jego i kapłanom i ludowi ziemi. I będą walczyć przeciw tobie, a nie przemogą, bo ja z tobą jestem, mówi Pan, aby cię wybawić." (Jr 1819) - wspomina słowa Pana Jeremiasz. Ogrom mocy, jaki Pan przelał na Jeremiasza, był nadludzki, boski. Nic więc dziwnego, że znając zamysł i cel Boga Jeremiasz boi się, waha i czuje, że ta rola go przerasta. Nie wie jeszcze, że przy bożej pomocy jest $\mathrm{w}$ stanie podołać nałożonemu na niego zadaniu. On będzie tylko narzędziem. Ustami przemawiać będzie Bóg. O ciężarze „bycia namaszczonym przez Boga" świadczą późniejsze męki, jakie przeżywał Jonasz starając się nawrócić zatwardziały lud oddający cześć bożkom. Nie dziwi więc fakt, ze Mojżesz w chwili powołania rzekł do Boga: „Proszę, Panie! nie jestem wymowny od wczorajszego i dziś trzeciego dnia; a odkądeś przemówił do sługi twego, stałem się niesposobniejszego i nierychlejszego języka (Wj 4,10-11). Bóg zapewnia go, że natchniony Duchem Świętym będzie wiedział, co mówić: „Idźże tedy, a ja będę w ustach twoich i nauczę cię, co masz mówić.(...) A on rzekł: Proszę, Panie! poślij, kogo masz posłać!" - upiera się Mojżesz (Wj 4,12), doprowadzając Boga do gniewu. „Rozgniewany Pan na Mojżesza, rzekł: Aaron, brat twój, Lewita, wiem, iż wymowny jest. Oto ten wynajdzie naprzeciw ciebie, a ujrzawszy cię rozraduje się sercem" (Wj 4,14). Kolejny przykład - prorok Ezechiel, którego Bóg posłał „do synów Izraelowych, do narodów odstępnych, które odstąpiły ode mnie; oni i ojcowie ich przestąpili przymierze moje aż do dnia tego. A są to synowie zatwardziałego oblicza i nieposkromionego serca, do których ja ciebie posyłam; a powiesz do nich: To mówi Pan Bóg” (Ez 2,3-5). I dalej Pan napomina: „Ty zaś synu człowieczy słuchaj, co Ja mówię do ciebie i nie bądź buntownikiem" (Ez 2,8).

W tym miejscu przywołajmy postać św. Pawła, który - po wszystkich swoich doświadczeniach, począwszy od nawrócenia w drodze do Damaszku, po liczne prześladowania - wyznaje w pierwszym liście do powstającej wspólnoty kościelnej w Koryncie: „Biada mi bowiem, gdybym nie głosił Ewangelii!” (1 Kor 9,16). A w kolejnym liście do Koryntian dodaje: „Nie głosimy bowiem siebie samych, lecz Chrystusa Jezusa jako Pana, a nas - jako sługi wasze przez Jezusa" (2 Kor 4,5). Św. Paweł mówi to po swym nawróceniu, jako apostoł pogan budujący w trudzie i niebezpieczeństwie Kościół Chrystusowy. Jak pisze prawosławny teolog, ks. Henryk Paprocki, wspólnota Kościoła (koinonia), ,jest specyficznym wyrażeniem oznaczającym obecność Ducha Świętego (...) we wspólnocie z Bogiem i w Bogu, wejściu przez akcję Ducha Świętego w sferę łaski Bożej, która jednoczy nas z Trójcą Świętą, adopcję dzieci Bożych (Ga 4,4-6; Rz 8,14)". Objawienie Chrystusa, Głowy Kościoła, dokonuje się dzieciom Bożym przez Ducha Świętego, a rola Ducha Świętego polega na przemienieniu wspólnoty w „Kościół Boży”. W tym sensie, możemy mówić o dynamizmie eschatologicznym tradycji, która dokonuje się w Bogu i z Bogiem w ciągu historycznym (Paprocki, 2012, s. 17).

\section{Trynitarność}

Nie da się oddzielić boskości Syna od Jego Ojca i Ducha Świętego. Wszystkie hipostazy zawsze działają łącznie i żadna z hipostaz nie działa samodzielnie. Trzy osoby, ale jedna natura. Dlatego, mówiąc o medialności Logosu, nie można pominąć teologii trynitarnej (a także jej medialności), która - w Kościele Wschodnim - jest podstawą dogmatyki i podwaliną wiary (Kupryjaniuk, 2017, s. 249-261). Św. Bazylii Wielki, jeden z Ojców Kapodockich, jako pierwszy dokonał opracowania terminologii Trójcy Swiętej, określając Ją jako jedną istotę i trzy hipostazy, będące względem siebie relacyjnie połączone i ustosunkowane jako: wspólistotne, a ich indywidualne cechy i przymioty, wynikające z relacji względem siebie, rozróżniają je od siebie. Hipostaza jest nierozerwalnie związana z niepoznawalną istotą (Św. Bazyli Wielki, 1972, s. 287), przy czym każda jest odrębną hipostazą - Ojciec jest wspótistotny Synowi i Duchowi, ale odrębny od ich hipostazy (Św. Bazyli Wielki, s. 155, W: Kupryjaniuk, s. 256). Ojciec jest przyczyną, świętością niemającą początku i niezrodzoną, Syn przed wiekami, przed czasem jest zrodzony z istoty Ojca, a Duch pochodzi od Ojca poprzez Syna ${ }^{18}$. Św. Ba-

\footnotetext{
18 Symbol wiary jest podstawą teologii dogmatycznej, w którym zawarte są kościelne prawdy wiary Kościół Wschodni, Ortodoksyjny, w odniesieniu do dogmatu o Trójcy Świętej opracowanego w trakcie pierwszych soborów nie przyjął spornego sformułowania „filioque”, podtrzymując w nauce teologii trynitarnej, że Trzecia Osoba Trójcy Świętej, Duch Święty, bytem swym pochodzi od Ojca, zaś w świat przyszedł poprzez
} 
zylii Wielki stwierdza nawet, że żadne stworzenie boskie nie posiada żadnego daru, które nie pochodziłoby od Ducha Świętego. O znaczeniu i roli trzeciej hipostazy poucza nas sam Nauczyciel. „Gdy jednak przyjdzie Pocieszyciel, którego Ja wam poślę od Ojca, Duch Prawdy, który od Ojca pochodzi, On będzie świadczył o Mnie" (J 15,26). A więc dopiero w dniu Pięćdziesiątnicy po zesłaniu Ducha Świętego na apostołów (J 20, 19-23) „,wspólnota Kościoła otrzymała dar Ducha Świętego od wywyższonego Chrystusa, który wstąił do nieba, by zasiąść po prawicy Ojca jako eschatologiczny król (Dz 2,33) (Nalewaj, 2011, s. 212-222). Od tego momentu możemy mówić o Kościele, który jest mistycznym Ciałem Chrystusa (Hrycuniak, Baczyński, 2017, s. 373-404) i kontynuacją Pięćdziesiątnicy, Kościołem wszechwładnym Trzech Osób Świętych (Evdokimov, 1986, s. 158), którego głową jest Chrystus (Paprocki, 2010, s. 294).

W wymiarze indywidualnym, proces stawania się żywym członkiem Ciała Chrystusa dokonuje się tylko wewnątrz Kościoła. Apostoł Paweł w Liście do Efezjan podkreślał, że celem człowieczeństwa jest „w Chrystusie połączyć w jedną całość wszystko, i to co jest na niebiosach i to, co jest na ziemi w Nim" (Ef 1,10). Kościół wedle tego, co powyżej, nie jest więc ani instytucją ani doktryną, tylko ,żywym organizmem prawdy i miłości, przenikniętym duchem soborowości. Tak rozumiany Kościół jest również idealnym organizmem społecznym" (Paprocki, 2010, s. 299). W tym świetle temat medialności nabiera szerszego znaczenia. Szczególnie w odniesieniu do nauki Ojców, którzy podkreślają, że „Kościół to żywy organizm, jedność miłości, niewypowiedziana wolność”, to „życie łaski” (Paprocki, 2010, s. 294-295). Z kolei życie każdego chrześcijanina staje się także wewnętrznym życiem Kościoła (Chomiakow, T. 2, 1900, s. 54, W: Paprocki, 2010, s. 295). Warto podkreślić, że Jego Eminencja Metropolita Sawa podkreśla, iż w ekonomii zbawienia każdy element żywego Kościoła jest nierozerwalnie złączony z innymi członkami Kościoła (Hrycuniak, 2003). Jak czytamy w Dziejach Apostolskich - ,jedno serce i jedna dusza” (Dz 4,32), tak też wszyscy chrześcijanie stanowią jedno ciało, składające się z wielu członków, będąc ciałem Głowy Samego Chrystusa $(\text { Ef } 4,15)^{19}$. Nie ma więc indywidualnej, oderwanej od jedności z całym organizmem, drogi. Tylko w Chrystusie człowiek uświęca się, oczyszcza i odradza. Jak zatem działa Chrystus w świecie?

\section{Kośció1}

Jak zaznacza ks. Metropolita Sawa, „Spotkanie człowieka z Bogiem jest możliwe tylko dzięki Duchowi Świętemu" (Hrycuniak, Baczyński, 2017, s. 373-404). I jedno-

\footnotetext{
Syna.

19 „Natomiast żyjac prawdziwie $w$ miłości sprawmy, by wszystko rosło ku Temu, który jest Głowa - ku Chrystusowi. Z Niego całe Ciało - zespalane $i$ utrzymywane $w$ tączności dzięki całej więzi umacniajacej każdy z członków stosownie do jego miary - przyczynia sobie wzrostu dla budowania siebie $w$ miłości”. (Ef 4, 15).
}

cześnie podkreśla także przy tym, że jest „to kontynuacja i spełnienie zbawczej misji Chrystusa, a uczestnikiem tego zbawczego dzieła można się stać tylko w Kościele Chrystusowym za pomocą Ducha Świętego, gdyż tylko w Kościele człowiek osiąga zbawienie i staje się uczestnikiem Bożej natury (Evdokimov, 1986, s. 159). Dlatego więc trzeba, abyśmy na moment zatrzymali się teraz na człowieku i Kościele.

Antropologia Kościoła Wschodniego zawsze określa Boga nakierowanego ku człowiekowi. Dlatego też mistyka Kościoła Wschodniego to transcendentalna łączność stworzenia z jego Stwórcą, opierająca się na sakramentalnej łączności życia duszy człowieka w przebóstwionym Chrystusie. Francuski teolog prawosławny Paul Evdokimov wskazuje nawet, że antropologia prawosławna nie jest antropologią moralną, tylko ontologiczną, gdyż jest ontologią przebóstwienia (Theosis), gdzie samo przebóstwienie, jak zaznaczali Ojcowie, to najwyższy dar dany człowiekowi przez Boga i zarazem ostateczny cel istnienia człowieka. Jego droga do zbawienia (Evdokimov, 1986, s. 120).

$\mathrm{U}$ podstaw pojęcia theosis (przebóstwienie), w świetle tradycji prawosławnej, leży rozróżnienie transcendentnej istoty Boga-Stwórcy od jego Bożych energii, dostępnych Jego stworzeniu - człowiekowi w doświadczeniu mistycznym. Za pośrednictwem boskich energii możliwym staje się wspólnotowe uczestniczenie przebóstwionego człowieka w samym Bogu (Mantzaridis, 1997, s. 40-45). Odnosząc się do teorii przebóstwienia, Święci Ojcowie wskazywali na moment, w którym Stwórca dokonał stworzenia najdoskonalszego ze stworzeń Boskich - człowieka. Jak czytamy w Piśmie, Bóg stworzył człowieka na swój „obraz i podobieństwo" (Rdz 1,27), jednak - mimo tego - człowiek nie wytrwał $\mathrm{w}$ tej wspólnocie $\mathrm{z}$ Bogiem, i poprzez upadek pierwszego człowieka, w naturze ludzkiej zatarł się „obraz” Boży, a w konsekwencji - przeznaczenie, na jakie Bóg naznaczył człowieka stało się własnymi, ludzkimi siłami nieosiągalne, a nawet przez człowieka zapomniane (Mantzaridis, 1997, s. 22-23). Dopiero kenoza, wcielenie Boga-Słowa, Boga-Syna, który stał się człowiekiem odmieniło dotychczasowy stan ludzkiej natury i dało człowiekowi możliwość, by ponownie upodobnić się do Boga (w Chrystusie dokonuje się ponowne uświęcenie ludzkiej natury). Po utraconej łączności stworzenia ze swoim Stwórcą, która była wynikiem upadku, następuje ponowne jednoczenie się człowieka z Bogiem. Z tym, że przebiega ono teraz, jak zaznacza Evdokimov, „od pneumatoforycznego świata wewnętrznego, przez kształtowanie Chrystusowe, jako członkowie teandrycznego Ciała, aż do otchłani Ojca" (Evdokimov, 1986, s. 143). Wszystko to dzieje się więc dzięki Duchowi Świętemu, poprzez którego Chrystus zstępuje do Kościoła z darem przebóstwienia, gdyż Duch Święty jest Duchem komunii. Przez Ducha i w Duchu tworzy się Kościół, Duch przemienia wspólnoty w „Kościół Boży”.

Nauka o Duchu Świętym i Jego działaniu (Evdokimov, 2012, s. 128; Evdokimov, 1986, s. 198-199) zakłada więc, że kenoza jest możliwa tylko w Kościele. „Duch Święty przebóstwia ludzkość i dlatego Kościół w swej najgłębszej strukturze jest przebóstwionym człowieczeństwem, ponie- 
waż uczestnicy Eucharystii dostępują przebóstwienia przez udział w Ciele i Krwi Chrystusa, gdyż Chrystus jest obecny w darach eucharystycznych przez działanie Ducha Świętego" - pisze ks. Paprocki (Paprocki, 2012, s. 30.). Ma to wymiar nie tyle teologiczny, co poznawczy, gdyż doświadczenie mistyczne jest możliwe tylko dzięki wstępowaniu od Ducha Świętego, poprzez Syna, do Ojca. Indywidualne przeżycie mistyczne, to nieustanna droga prowadząca przez ascetyczne życie duchowe do ,stopniowego wstępowania ku rajskiej drabinie” (Św. Jan Klimak, 2011). Jest to „Pięćdziesiątnica kontynuowana w czasie aż do paruzji" (Paprocki, 2012, s. 30), a więc ponownego przyjścia Chrystusa. Pisząc o znaczeniu Pięćdziesiątnicy prawosławny teolog, Aleksander Schmemann, podkreśla, że tego dnia „Duch zstąpił na Kościół i przebywa w nim jako jego życie" (Schmemann, 1988, s. 46-47). W tym też kontekście francuski teolog, P. Evdokimov kontynuuje, że od tej właśnie chwili „Duch bliższy jest nam niż my sami sobie" (Evdokimov, 1986, s. 343).

Ks. H. Paprocki kontynuuje dalej swą myśl podkreślając, że „Kościół jest jednością w jednej łasce Bożej, która jednoczy przeszłe, obecne i przyszłe pokolenia" (Paprocki, 2010, s. 297). Wskazuje tym samym na ciągłość historyczną procesu tworzenia się i trwania Kościoła. Także P. Evdokimov zwraca jednocześnie uwagę na bardzo waży aspekt historyczności dzieła zbawczego, jakie dokonuje się w Kościele. Logos, jak zaznacza, objawia się w Kościele w sposób ukryty, objawia się w Kościele niewidzialnym, w kościele pozabiblijnych pogan, co w kontekście historycznym wskazuje na ciągłość ciała historycznego, które zostało ustanowione jako Kościół. „Kościół istniał przed wiekami i jest celem stworzenia (Evdokimov, 1986, s. 139) - podkreśla francuski teolog. Pocieszyciel, Duch Święty zesłany apostołom w dniu Pięćdziesiątnicy (i posyłany ich następcom dzisiaj), o którym mówił Jezus swym uczniom jeszcze przed ukrzyżowaniem, kontynuuje dzieło Zbawiciela w świecie ${ }^{20}$.

Pisząc o doświadczeniu Ducha Świętego w Kościele prawosławnym, ks. Henryk Paprocki wskazuje na dwa wymiary tego przeżycia: wspólnotowy i indywidualny. Pierwszy przejawia się w Boskiej Liturgii eucharystycznej, która opiera się na epiklezie (modlitwie wzywającej Ducha Świętego) - w centrum Liturgii zawsze znajduje się Duch Święty, od modlitw początkowych, aż po sakramenty, z Eucharystią na czele. W Eucharystii wszak spożywamy realne Ciało Chrystusa, ,a wiec przyjmujemy Chrystusa i Ducha Świętego" (Paprocki, 2012, s. 19). Teolog określa nawet spożywanie samego Zmartwychwstałego paruzją eucharystyczną, każdorazowym świętem Pięćdziesiątni$\mathrm{cy}^{21}$ (zstąpienie Ducha) przy jednoczesnym podkreśleniu wspólnoty (gr. koinonia) uczestniczenia w zmartwychwstałym Ciele Jezusa Chrystusa ${ }^{22}$.

\footnotetext{
20 Stichos na święto Pięćdziesiątnicy, który śpiewany jest w cerkwi tego dnia, głosi: „Królu Niebieski, Pocieszycielu, Duchu Prawdy, który wszędzie jesteś i wszystko napełniasz, Skarbnico dóbr i Dawco życia, przyjdź i zamieszkaj w nas, i oczyść nas z wszelkiej zmazy, i zbaw, o Dobry, dusze nasze".

${ }_{21}$ Święto zesłania Ducha Świętego na apostołów po pięćdziesięciu dniach od Zmartwychwstania Pańskiego.

${ }^{22}$ Prosimy Ojca, aby zesłał Ducha Świętego i przemienił chleb w Ciało Chrystusa, a wino w Jego Krew. Czegokolwiek bowiem dotknie Duch
}

Aspekt indywidualny z kolei - pisze dalej ks. Paprocki - dotyka doktryny hezychastycznej ${ }^{23}$, którą rozwinęli w XIV w. mnisi Świętej Góry Atos. Dzięki Świętemu Grzegorzowi Palamasowi, który stając w obronie hezychazmu przed oskarżeniami o herezję, wiemy, że doświadczanie Boga nie jest tożsame z próbą obcowania z niepoznawalną dla człowieka istotą Boga, ale z poznawalnymi w doświadczeniu mistycznym Boskimi energiami (czyli objawianiem się Boga na zewnątrz - nie my „dotykamy się Boga”, a On nas). „Hezychia jest więc drogą, dzięki której człowiek może wejść w bezpośredni, egzystencjalny kontakt z Bogiem. Bóg może być oglądany, gdyż energie są Jego objawieniem, dostępnym dla człowieka" (Paprocki, 2012, s. 32; Paprocki, 2001, s. 85-97). Nic jednak nie dzieje się bez udziału Ducha Świętego, bez daru łaski Bożej, dlatego też, idąc dalej na kanwie tego, co powyżej, Św. Serafin z Sarowa stwierdzi w rozmowie ze swoim uczniem Mikołajem Motowiłowem, że „,elem życia chrześcijanina, jest zdobywanie Ducha Świętego", który zaprasza nas do tej wspólnoty. Umożliwia ją (Św. Serafin z Sarowa, 2018, s. 76). Widzimy więc, że medialność po Zmartwychwstaniu, po Pięćdziesiątnicy, po ustanowieniu Kościoła Chrystusowego, nabiera zupełnie innego wymiaru. Nie opowiada o Bogu, a buduje wspólnotę z nim. Odkrywa niepoznawalnego poprzez spotkanie i więź - Eucharystię, komunię (a komunię dużą czy małą literą?). Nie „prowadzi człowieka do Boga a Boga ofiarowuje człowiekowi”. Bóg staje się tu człowiekiem, by człowiek stał się bogiem (nie z natury a poprzez łaskę).

Kluczową rolę odgrywa tu Duch Święty, Trzecia Osoba Trójcy Świętej, o której wiemy, że „działa tam, gdzie chce i jak chce", gdyż jest on wolnością (Paprocki, 2012, s. 16-18). Dlatego też - jak pisze ks. Paprocki - nauka o pneumatologii i eklezjalnej obecności Ducha Świętego w Kościele nie jest: „osobnym traktatem teologicznym, lecz sercem teologii chrześcijańskiej” (Paprocki, 2001, s. 85-97). Podobnie dary Ducha Świętego nie są rządzone przez żadne prawo, gdyż mówiąc słowami apostoła Pawła, „Wiatr wieje gdzie chce. Szum jego słyszysz, lecz nie wiesz, skąd przychodzi i dokąd zmierza. Tak samo bywa z każdym, kto się z Ducha narodził" (J 3,8) (Paprocki, 2012, s. 16-17). Na kanwie tej pojawia się jeszcze kolejny ważny aspekt dotyczący człowieka, który wskazał P. Evdokimov. Pisząc o życiu duchowym człowieka, a co za tym idzie także i doświadczeniu mistycznym, zauważył on, że istnieją trzy rodzaje woli działające w człowieku: element boski, ludzki i demoniczny. Przy czym tylko element boski jest całkowicie transcendentalny i objawia się

Święty, to wszystko jest uświęcone i przemienione (Św. Cyryl Jerozolimski, 1973)

23 Hezychazm (od greckiego ' $\eta \sigma v \chi i \alpha$, hēsychía) - wyciszenie, praktyka mnisza, rozwinięta na przełomie XIII i XIV w. przez mnichów na Świętej Górze Atos, dążąca do osiągnięcia stanu mistycznego zjednoczenia człowieka z Bogiem dzięki trwaniu w nieprzerwalnej modlitwie oraz praktykom ascetycznym, aby osiągnąć stan „czystej modlitwy”, beznamiętności (gr. A $\pi \alpha \theta \varepsilon 1 \alpha$, apathia). Dzięki oczyszczeniu się z ludzkich namiętności człowiek dostępuje możliwości przebywania z Bogiem. W XIV w. praktyka ta została obroniona przez św. Grzegorza Palamasa przed zarzutem herezji. 
jako dar. Również wspomniany już wyżej apostoł Paweł podkreśla w Liście do Efezjan, iż obecność Boża w człowieku jest czystą łaską i jest całkowicie transcendentalna (Evdokimov, 1986, s. 139-153). Apostoł poucza także, że człowiek, który rozpoczyna życie w Chrystusie musi ,porzucić dawnego człowieka, który ulega zepsuciu na skutek zwodniczych żądz, odnawiać się duchem (...), i przyoblec człowieka nowego, stworzonego według Boga, w sprawiedliwości i prawdziwej świętości” (Ef 4,22-5,20). Jak to uczynić?

\section{Medialność Boga - Beze mnie nic nie możecie uczynić}

Medialność w Boskim dziele zbawienia nie jest jedynie prostym głoszeniem własnych poglądów, musi łączyć propagowanie idei z życiem zgodnie z jej treścią. Jest realizacją treści głoszenia. Od początku dziejów, pośredniczenie w relacji Stwórca-stworzenie było dla człowieka na tyle trudne do zniesienia, że mogło odbywać się wyłącznie przy wsparciu Bożym. Jezus mówiąc do swych uczniów „beze mnie nic nie możecie uczynić” (J 15,5), poucza, że tylko Boża siła, Bóg w Trójcy Świętej, podoła niemożliwemu. Bez Boga apostołowie nie mogliby uczynić tego, do czego zostali powołani, co doskonale ukazuje opisane wyżej święto Pięćdziesiątnicy - żeby nauczać o Bogu musieli Go przyjąć (Pięćdziesiątnica). Także Jezus w tym kontekście nie może nie zostać odczytany wyłącznie jako Syn Boży. Jego medialność i posłannictwo, nieodzownie łączyły się z publiczną funkcją, jednak stanowiły dwa różne aspekty tej samej roli, jaką - swym wcieleniem i zmartwychwstaniem - dopełnił na ziemi. Pokonanie śmierci, przebóstwienie człowieka, odkupienie z grzechów, życie wieczne w Bogu i wszelkie nauki Dobrej Nowiny - zmieniły postawę wszelkiego stworzenia wobec Stwórcy.

Św. Klemens Aleksandryjski wskazywał, że „Słowo Boże stało się człowiekiem, abyś nauczył się za pośrednictwem Człowieka, jak człowiek może się stać Bogiem według Łaski”" (Evdokimov, 1986, s. 141). Bóg stał się człowiekiem, by człowiek usłyszał Go, zrozumiał i pokochał, ponieważ Bóg - w swym miłosierdziu - dąży do tego, by zbawić jak największe rzesze ludzi. Wykorzystuje różne środki, by dotrzeć do każdego człowieka, a jej formy - zwiastowania, zawsze dostosowuje do okoliczności i czynników, zarówno historyczno-kulturowych, politycznych i społecznych, jak i indywidualnych.

Nie dziwi więc fakt, że nowe wyzwania współczesności od dłuższego już czasu stanowią przedmiot rozważań także wewnątrz Kościoła. Kościół kontynuuje dyskusję wokół tego, jak wykorzystać nowe narzędzia do tego, by wyjść naprzeciw wiernym (Siwek, 2011, s. 292-309) i jak w nowych formach zmieścić odwieczne treści. Medialność wszak sprzyja upowszechnianiu idei i wartości, a także podnosi szybkość ich docierania do odbiorcy (Nitecki, 2003, s. 88-89). Taką formę komunikacji można zaprząc w służbę współczesnego człowieka i Ewangelii. Dotyczy to zarówno sfery sacrum, jak i profanum. Nie ma znaczenia, czy będziemy promować książkę kucharską, czy Pismo Święte. Współczesne media równie dobrze sprawdzą się w obu przypadkach. Podniosą sprzedaż. Zainteresują czytelnika.

Jest jednak jedna zasadnicza różnica. Chodzi o skutki, jakie daje nam odpowiednie operowanie tą medialnością w tych zgoła odmiennych przypadkach. Dzięki książce kucharskiej nakarmimy dobrem nasze ciało, które i tak się rozpadnie - odroczymy nieuchronne. Dzięki Ewangelii nakarmimy duszę i ciało, które ma przecież trafić do królestwa niebieskiego i pozostać w nim na wieczność - wbrew temu co wydawało się nieuchronne. Technika, jak widać ta sama, ale cel i skutki zupełnie inne.

Dawniej, a także i dzisiaj pojawiają się oczywiście argumenty, że Słowo Boże nie potrzebuje medialności, jako słowo życia i Boga samo sobie poradzi. To prawda. Nie zmienia to jednak faktu, że sam Jezus był postacią medialną. W tym co robił, starał się być tak doskonałym, jak On sam - Bóg. Uczniów swych, a wiec i nas, uczył, byśmy byli podobni do Niego. Jeśli On uznał medialność za właściwą drogę, to może należałoby Mu zaufać?

Medialność nie wartościuje przekazywanych treści, nie powinna ich tym bardziej modyfikować. Boże treści same w sobie są piękne i bogate. Medialność ukierunkowana jest nie na to, co przekazujemy, ale na tego, komu przekazujemy. Ma przełamywać jego słabości i niedoskonałości, a nawet nierozsądek i bezsensowny opór. By ten, który ma uszy, usłyszał, a ten, który ma oczy, dojrzał. I przede wszystkim - poznał Boga ${ }^{24}$.

24 Poznanie Boga-jak zaznacza apostoł Paweł w liście do Galatów (Gal 4,9) - jest Objawieniem Boga, zależnym od Niego. Evdokimov dodaje, że jest także „niczym niezasłużone” przez człowieka. Św. Grzegorz z Nyssy przypomina równocześnie, że poznanie to jest zawsze charyzmatyczne. Człowiek stworzony na obraz Boży nosi w sobie wrodzoną łaskę kontemplacji Boga. Ten dialog między Bogiem a duszą człowieka jest przebóstwiający, gdyż jednoczy go ze Stwórcą. Jest Objawieniem w jedności Trójcy Świętej, ponieważ: ma ono swe źródło w Bogu Ojcu, a dokonuje się w Synu poprzez Ducha Świętego. Apostoł Jan, mówiąc o tym, że człowiek ,(...) mieszkanie u Niego uczynimy” (J 14,23) wyraża objawienie w sensie komunijnym. Błogosławieństwem jest mieszkanie Boga w człowieku. Obecność Boga w duszy, poczucie duchowej bliskości i obecności Boga, jest mistycznym obcowaniem z Jego Boskimi energiami.

\section{Bibliografia}

Bartoszewicz, D. (2014). Środki wyrazu w Księdze Jonasza. Warszawskie Studia Teologiczne (XXVII/2, s. 195-201). Warszawa.
Biblia Ekumeniczna. Pismo święte Starego i Nowego Testamentu z ksiegami deuterokanonicznymi. (2018). Warszawa: Towarzystwo Biblijne w Polsce. 
Bóg żywy. Katechizm Kościoła Prawosławnego. (2001). (A. Kuryś, Tłum.). Kraków: WAM

Batut, J. P. (2006). Teologiczne odczytanie chrztu Jezusa. Communito, 1(151), 9-20.

Charkiewicz, J. (2013). Biblijna nauka o świętości człowieka. Elpis, 27 (40), 99-106.

Chmielewski, M. (2014). Media społecznościowe jako narzędzia nowej ewangelizacji. Świat i Słowo (22), 213-230.

Brzegowy, T. (2008). Czy Izajasz zapowiadał Mesjasza? Collectanea Theologica, 78/3, 5-27. Warszawa.

Brzegowy, T. (2014). Prorocy Izraela. (cz. I, s. 94-96.). Tarnów: Wydawnictwo Diecezji Tarnowskiej BIBLOS.

Homâkov, A. (1900). Polnoe sobranie sočinenij. (t. 2). Moskva [Хомяков, А. (1900). Полное собрание сочинений. (t. 2). Москва]

Charkiewicz J. (2013). Biblijna nauka o świętości człowieka. W: Elpis, 27 (40). 2013.

Św. Cyryl. Jerozolimski. (1973). Katechezy. Warszawa: Akademia Teologii Katolickiej.

Św. Jan Damasceński. (1969). Wykład wiary prawdziwej. Warszawa: PAX.

Evdokimov, P. (1964). Prawostawie. Warszawa: PAX.

Evdokimov, P. (2012). Duch Święty w tradycji prawosławnej. Poznań: W Drodze.

Gasset, O. (2002). Bunt Mas. Warszawa: MUZA.

Hajduk, R. (2012). O głoszeniu Ewangelii i marketingu narracyjnym. Studia Warmińskie, 49, 151-164.

Jaworski, P. (2015). Stary Testament zapowiada Jezusa Chrystusa. Radiowo-Internetowe Studium Biblijne, (W. 8), 1-6. Warszawa.

Lachowicz, J. (1994). Angelologia św. Grzegorza Wielkiego. Studia Teologiczne, 12, 153-186. Białystok - Drohiczyn Łomża.

Langkammer, H. (1993). Mały stownik biblijny. Wrocław: Wydawnictwo św. Antoniego.

Lewandowski, J. Spis ludności za Kwiryniusza. [online] apologetyka.info.pl, [12.05.2019].

Lemański, J. (2002). Dobra nowina według Deutero-Izajasza (Iz 52,7-10). Verbum vitae, 2/2002, 49-64.

Lewek, A. (1998). Mass-media w służbie ewangelizacji. Studia Theologica Varsaviensia, 36/2, 89-98. Warszawa.

Lyotard, J.-F. (1997). Kondycja Ponowoczesna. W: Sztuka i Filozofia. Warszawa: Aletheia. [online] http://bazhum.muzhp. pl, [28.03.2019].

Łosski, W. (1989). Teologia Mistyczna Kościoła Wschodniego. Kraków: Wydawnictwo Uniwersytetu Jagiellońskiego.

Meyendorff, J. (2007). Teologia bizantyjska, historia i doktryna. Kraków.

Mantzaridis, G. I. (1997). Przebóstwienie czlowieka nauka świętego Grzegorza Palamasa w świetle tradycji prawosławnej. Lublin: Wyd. Diecezji Lubelsko- Chełmskiej.

McLuhan, M. (2004). Zrozumieć Media, Przedtużenia Człowieka. Warszawa.
Św. Nikołaj Serbski. (2008). Homilie. Hajnówka: Bratczyk.

Nalewaj, A. (2011). „Logion” o wywyższeniu Syna Człowieczego w dialogu Jezusa z Nikodemem (por. J 3,14-15). Studia Elbląskie, 12, 211-222.

Nitecki, P. (2003). Media - ewangelizacja - człowiek. Legnickie Studia Teologiczno-Historyczne. Perspectiva, 2003 (2), 85-97.

Otto, R. (1999). Świętość. Warszawa: Aletheia.

Orłowski, P. (1994). Walter Benjamin i filozofia. Sztuka i Filozofia, 9, 203-208.

Paprocki, H. (2010), Eklezjologia Aleksego Chomiakowa. Elpis, 12/21-22, 291-303.

Paprocki, H. (2001). Obietnica Ojca Doświadczenie Ducha Świętego w Kościele Prawostawnym. Bydgoszcz: Homini.

Paprocki, H., Hryniewicz, W., Karski, K. (2010). Credo symbol wspólnej wiary. Kraków: ZNAK.

Paprocki, H. (2014). Zarys prawosławnej nauki o Duchu Świętym. Elpis, 14, 11-39.

Pismo Święte Starego i Nowego Testamentu - w przekładzie Jakuba Wujka. (1962). Kraków: Wyd. Apostolstwa Modlitwy.

Psałterz złożony. (2017). (H. Paprocki, Tłum.). [online] http:// www.liturgia.cerkiew.pl, [12.02.2019].

Paciorek, A. (2006). Ewangelia wedtug św. Mateusza. Kraków: Wydawnictwo WAM.

Św. Paisjusz H. (2012). Słowa 1-5. Hajnówka: Bratczyk.

Hrycuniak, Sawa (metropolita). (2003). Chrystus najwierniejszy przyjaciel człowieka. Warszawa: Warszawska Metropolia Prawosławna.

Hrycuniak, Sawa (metropolita), Baczyński, A. (2017). Duch Święty w dziele uświęcenia człowieka. Rocznik Teologiczny, 2017, 373-404 (378).

Synowiec, J. (1992). Oto twój król przychodzi, Mesjasz w pismach Starego Przymierza. Kraków.

Śmigiel, W. (2014). Jak głosić Jezusa Chrystusa w dobie nowej ewangelizacji? Rocznik Teologii Katolickiej, (t. XIII/2).

Komentarz Świętych Ojców do Ewangelii wedlug Świętego Mateusza. (2004). Hajnówka: Bratczyk.

Siwek, G. (2011). Posługa Słowa w epoce mediów. Studia Pastoralne, 7, 292-309.

Tomala, J. (1938). Teologia proroka Jeremiasza. Collectanea Theologica, 19/3, 318-385.

Twardy, J. (2007). Chrystocentryzm w kaznodziejskiej posłudze słowa. Ślaskie Studia Historyczno-Teologiczne, (t. 40, s. 5064.). Katowice.

Bazyli Wielki, św. (1972) Listy. Warszawa: PAX.

Wils, J. P. (2014). Religia jako kwestia nerwów. Wstępne rozważania nad archeologią bluźnierstwa. Studia kulturoznawcze, 2(6)/2014, 11-30.

Włodarczyk, J. (2005). Tajemnica Gwiazdy Betlejemskiej. Warszawa: Świat Książki.

Zagórski, D. (2009). Egzegeza Księgi Jonasza w pismach Grzegorza z Nazjanzu. Biblica Et Patristica Thoruniencja, 2, 116-125. 